Atmos. Chem. Phys., 13, 8381-8399, 2013

www.atmos-chem-phys.net/13/8381/2013/

doi:10.5194/acp-13-8381-2013

(c) Author(s) 2013. CC Attribution 3.0 License.

\title{
Evaluation of spatio-temporal variability of Hamburg Aerosol Climatology against aerosol datasets from MODIS and CALIOP
}

\author{
V. Pappas ${ }^{1}$, N. Hatzianastassiou ${ }^{1}$, C. Papadimas ${ }^{1}$, C. Matsoukas ${ }^{2}$, S. Kinne ${ }^{3}$, and I. Vardavas ${ }^{4}$ \\ ${ }^{1}$ Laboratory of Meteorology, Department of Physics, University of Ioannina, 45110, Ioannina, Greece \\ ${ }^{2}$ Department of Environment, University of the Aegean, Mytilene, Greece \\ ${ }^{3}$ Max Planck Institute for Meteorology, Hamburg, Germany \\ ${ }^{4}$ Physics Department, University of Crete, Heraklion, Crete, Greece
}

Correspondence to: N. Hatzianastassiou (nhatzian@cc.uoi.gr)

Received: 24 November 2012 - Published in Atmos. Chem. Phys. Discuss.: 22 February 2013

Revised: 28 May 2013 - Accepted: 5 July 2013 - Published: 22 August 2013

\begin{abstract}
The new global aerosol climatology named HAC (Hamburg Aerosol Climatology) is compared against MODIS (Collection 5, 2000-2007) and CALIOP (Level 2-version 3, 2006-2011) retrievals. The comparison of aerosol optical depth (AOD) from HAC against MODIS shows larger HAC AOD values over regions with higher aerosol loads and smaller HAC AOD values than MODIS for regions with lower loads. The HAC data are found to be more reliable over land and for low AOD values. The largest differences between HAC and MODIS occur from March to August for the Northern Hemisphere and from September to February for the Southern Hemisphere. In addition, both the spectral variability and vertical distribution of the HAC AOD are examined at selected AERONET (1998-2007) sites, representative of main aerosol types (pollutants, sea salt, biomass and dust). Based on comparisons against spectral AOD values from AERONET, the mean absolute percentage error in HAC AOD data is $25 \%$ at ultraviolet wavelengths $(400 \mathrm{~nm}), 6-12 \%$ at visible and $18 \%$ at near-infrared $(1000 \mathrm{~nm})$. For the same AERONET sites, the HAC AOD vertical distribution is compared against CALIOP space lidar data. On a daily average basis, HAD AOD is less by $9 \%$ in the lowest $3 \mathrm{~km}$ than CALIOP values, especially for sites with biomass burning smoke, desert dust and sea salt spray. Above the boundary layer, the HAC AOD vertical distribution is reliable.
\end{abstract}

\section{Introduction}

During the last decades, the scientific community has been trying to estimate the sign and magnitude of the individual factors contributing to the well-established net climate change since pre-industrial times. One of the greatest uncertainties in assessing what affects climate change is the interaction between clouds, aerosols and radiation (IPCC, 2007). Aerosols through scattering and absorption reduce the amount of short-wave radiation reaching the surface, resulting in surface cooling and warming of the atmosphere. This can have impacts on water evaporation from the surface and also in cloud formation and precipitation (IPCC, 2007; Lau et al., 2006; Su et al., 2010; Johnson et al., 2004). The primary sources of atmospheric aerosols are fires, deserts, oceans and fossil fuel combustion. Hence, aerosol modes and their radiative properties exhibit high temporal and spatial variability.

Ferrare et al. (2005) investigated the representation of the various types of aerosol (sulfate, black carbon, sea salt, particulate organic matter and dust) in various models and concluded that there are such large differences in their radiative properties that might explain inter-model differences in aerosol radiative effects. Textor et al. (2006) examined aerosol component life cycles for 17 aerosol modules used in the global models that participated in AeroCom initiative experiments and came to the same conclusion. Clearly, there is a need for a better understanding of variability in aerosol properties, especially that of the optical depth and its vertical distribution. 
The motivation for analysing aerosol optical depth (AOD) is that it is a good measure of atmospheric aerosol load and because it determines radiative effects, together with the aerosol single scattering albedo (SSA) and asymmetry parameter (ASY). Advances in surface- and satellite-based monitoring instruments during the last decade have enhanced our ability to measure AOD on a planetary scale. Groundbased stations such as those of the AErosol RObotic NETwork (AERONET) (Holben et al., 2001; Dubovik et al., 2006), and space-borne instruments such as the MOderate Resolution Imaging Spectroradiometer (MODIS) (Remer et al., 2005), the Multi-angle Imaging SpectroRadiometer (MISR) (Diner et al., 1998 ), the Total Ozone Mapping Spectrometer (TOMS) (Herman et al., 1997) and the Advanced Very High Resolution Radiometer (AVHRR) (Zhao et al., 2004) provide a comprehensive map of the spatial and temporal distribution of AOD over most of the globe. A synthesis of products from different satellite platforms should also improve estimates of AOD (Chatterjee et al., 2010).

There are numerous studies that have used either satellite products only or in combination with ground-based observations to estimate regional and global AOD (e.g. Papadimas et al., 2009; Kaskaoutis et al., 2011). Most studies have used satellite AOD products that refer to aerosol load, which is the aerosol amount integrated from the surface to the top of atmosphere. However, not only the horizontal but also the vertical distribution of aerosols is an important issue (Kaufman et al., 1997). Knowledge of the vertical structure of an aerosol layer is essential for modelling and understanding the processes that are involved (e.g. De Graaf et al., 2007), especially for estimating the aerosol direct (Abel et al., 2005), indirect and semi-direct effects (Penner et al., 2006) at the earth's surface, within the atmosphere and at the top of the atmosphere (TOA). There is great uncertainty in the vertical aerosol distribution (IPCC, 2007), and hence it has been the subject of a number of studies (e.g. Liu et al., 2008; Yu et al., 2010). Most of them, though, focus on a limited number of sites, where ground-based remote sensing instruments (lidars) are available to provide vertical profiling of aerosols. As these studies verify, the vertical distribution of aerosols varies significantly between sites and it is only very recently that one can obtain a global picture based on models and satellite observations (e.g. CALIPSO, CloudSat).

In order to derive characteristic aerosol properties on a full global scale and in three dimensions, complete and consistent fields - defined by AeroCom (Kinne et al., 2006) monthly median maps - have been improved with quality multi-annual monthly statistics from ground-based sun/sky photometry. For a complete description of the algorithms and methodology used for the construction of the Hamburg Aerosol Climatology (HAC), see Kinne et al. $(2008,2012)$. The main advantages of HAC are as follows: (1) it provides aerosol optical properties for all sub-spectral regions of the solar and infrared spectrum; (2) it provides the vertical distribution of AOD from the surface up to $20 \mathrm{~km}$ above mean sea level; and (3) it separates optical properties for fine and coarse aerosols, as well as for natural and anthropogenic aerosol.

The purpose of this study is to assess the performance of HAC AOD for use in climatological studies, by comparing it against contemporary and successfully validated satellite retrievals (Sect. 3). Although this has been shown indirectly in the past (Kinne et al., 2006) by assessing aerosol optical properties in 20 global models participating in the AeroCom experiment and also by comparing them against remote sensing retrievals, a longer period of MODIS data is used here (March 2000 to February 2007) compared to one year MODIS AOD data used in that study. Furthermore, Kinne et al. (2006) only presented mid-visible AOD, while this study also looks at the spectral performance of HAC AOD (Sect. 4). Finally, the vertical distribution of HAC AOD is evaluated here through comparison against CloudAerosol LIdar with Orthogonal Polarization (CALIOP) data from July 2006 to January 2011 (Sect. 5). It would be also important to evaluate the HAC SSA and ASY data, but here priority is given to AOD, first because of its primary importance for the computation of aerosol radiative properties and climatic effects, and secondly because at present there are enough available satellite- and surface-based AOD data for inter-comparison. Unfortunately, this is not the case, not only for SSA, but also for ASY.

\section{Data}

\subsection{Hamburg Aerosol Climatology (HAC)}

HAC provides all-sky aerosol optical properties for 14 solar and 16 infrared wavelengths, which complement the subspectral choices of rapid radiative transfer model (RRTM) schemes (Mlawer et al., 1997) and are applied in the ECHAM6 global model to describe atmospheric trace-gas absorption. Spectrally dependent aerosol single scattering properties (AOD, SSA and ASY) are provided on a monthly basis and at $1^{\circ} \times 1^{\circ}$ latitude-longitude resolution for the entire globe (ftp://ftp-projects.zmaw.de/aerocom/climatology/ feb_2010/).

The HAC central element is data-merging, including background maps from global modelling (median composite maps) and local quality data from the AERONET network. More than 10 different global models with detailed aerosol modules are used and AERONET data from 1998 to 2007 for more than 300 sites. The matching of model grids with AERONET stations is based on the representativeness of each AERONET site. The result is that if higher quality local data in a region are available, then they are used to modify regionally the background maps obtained from modelling. The merging process is initially applied to AOD, SSA and Ångström parameter (AnP) for the mid-visible wavelength of $550 \mathrm{~nm}$. Then, adopting a separation of contributions by 
a) Total
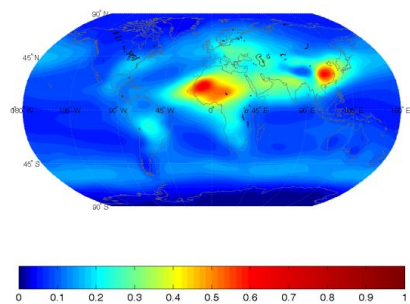

b) Anthropogenic

c) Natural

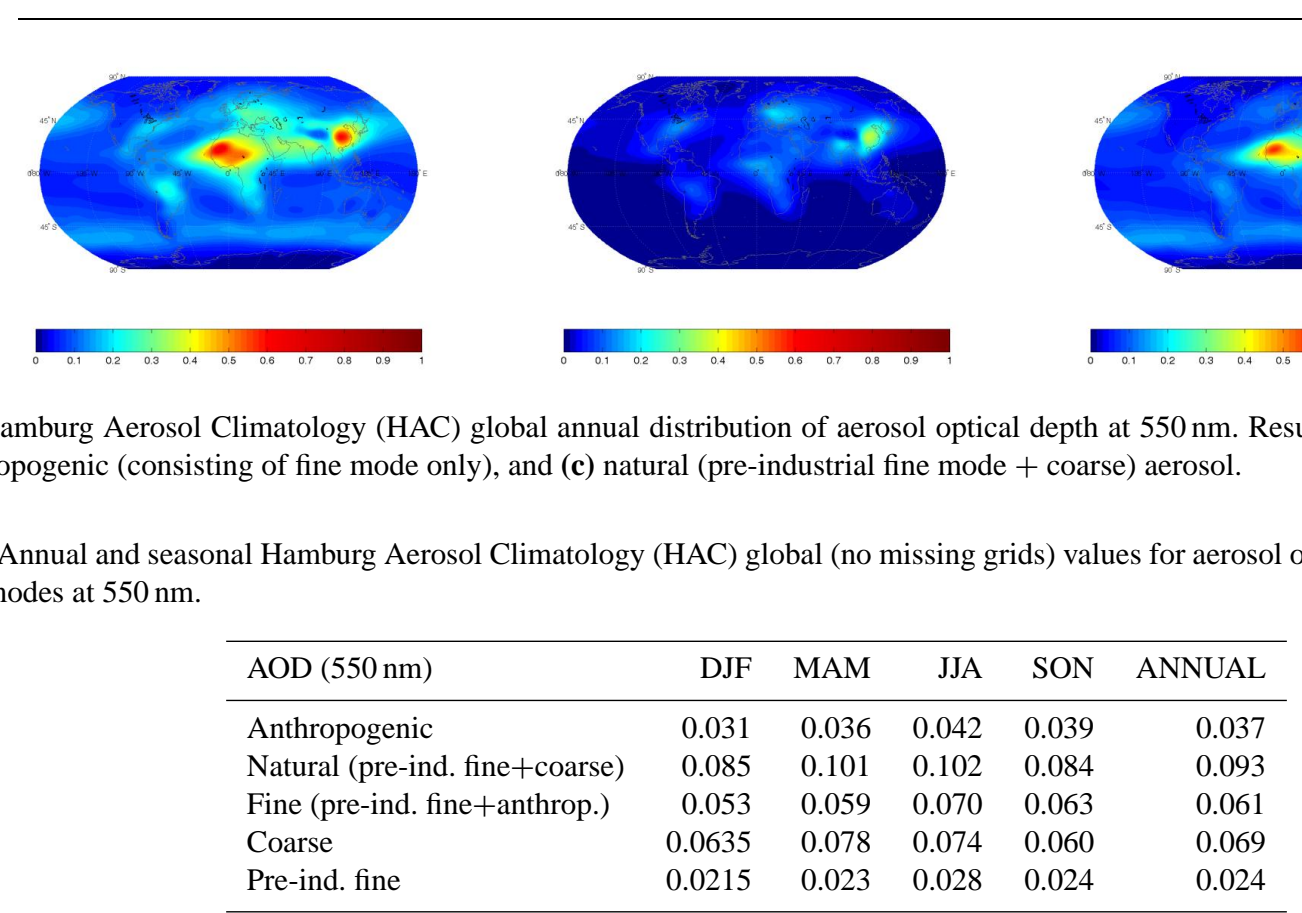

Fig. 1. Hamburg Aerosol Climatology (HAC) global annual distribution of aerosol optical depth at $550 \mathrm{~nm}$. Results are given for (a) total, (b) anthropogenic (consisting of fine mode only), and (c) natural (pre-industrial fine mode + coarse) aerosol

Table 1. Annual and seasonal Hamburg Aerosol Climatology (HAC) global (no missing grids) values for aerosol optical depth of the various aerosol modes at $550 \mathrm{~nm}$.

larger and smaller aerosol sizes, aerosol columnar properties for the other wavelengths of the solar and infrared spectrum are determined (Kinne et al., 2012). Finally, AOD is distributed over 20 pre-defined vertical levels extending from the surface to an altitude of $20 \mathrm{~km}$ based on simulations with HAM (Hamburg Aerosol Module) within ECHAM5 (Stier et al., 2007). Aside from an AOD separation into coarse and fine sizes, the mid-visible AOD in HAC is also separated into anthropogenic $\left(\mathrm{AOD}_{\text {anthrop}}\right.$, the difference between current and pre-industrial fine aerosol) and natural $\left(\mathrm{AOD}_{\text {natural }}\right.$, the sum of pre-industrial fine aerosol and coarse aerosol) components. For AOD, the following mixing formulas are valid:

$\mathrm{AOD}_{\text {total }}=\mathrm{AOD}_{\text {fine }}+\mathrm{AOD}_{\text {coarse }}=\mathrm{AOD}_{\text {natural }}+\mathrm{AOD}_{\text {anthrop }}$

Figure 1 shows a clear inter-hemispherical asymmetry of AOD with larger values in the Northern Hemisphere $(\mathrm{NH})$ than in the Southern Hemisphere (SH). This asymmetry is far stronger for anthropogenic (single peak near $30-50^{\circ} \mathrm{N}$ ) than natural AOD, which apart from a primary peak within $10-30^{\circ} \mathrm{N}$ also exhibits a secondary peak within $45-55^{\circ} \mathrm{S}$ (see also Fig. S2 of the Supplement). Anthropogenic aerosols (Fig. 1b) are dominant over heavily polluted areas, such as East Asia (largest fine AOD values), northern India, eastern and Central Europe and eastern United States. A fraction of AOD from wildfires is also considered anthropogenic with major contributions over the Amazon Basin (Holben et al., 1996; Fearnside, 2000) and western, central and southern Africa (Liousse et al., 1996; Swap et al., 1996; Johnson et al., 2008; Roberts et al., 2009). Anthropogenic AOD is mainly found over NH land, as well as over oceans due to transport from their sources. Averaging all grids across the globe and applying latitudinal weights, global anthropogenic $\mathrm{AOD}_{550}$ is found to be 0.037 (Table 1). The largest anthropogenic AOD occurs during NH summer and autumn (corresponding to 1.14 and 1.05 times the mean annual global anthropogenic AOD). Natural aerosols are systematically found above the deserts of Sahara, Saudi Arabia, Gobi and Taklamakan (Fig. 1c). Larger values of natural AOD also appear over the southern oceans at latitudes between $45^{\circ} \mathrm{S}$ and $60^{\circ} \mathrm{S}$, mainly sea salt type, as reported by other studies (Chin et al., 2002; Penner et al., 2002). Some dust outflow from Patagonia is also evident at $40^{\circ} \mathrm{W}$, in agreement with observations (Johnson et al., 2011). The global natural AOD (at $550 \mathrm{~nm}$ ) is 0.093 , which is almost three times larger than the global anthropogenic AOD (Table 1). Both the temporal and seasonal distributions of natural AOD differ from the distributions for anthropogenic aerosol. Natural AOD maxima in $\mathrm{NH}$ spring and summer are driven by dust contributions from northern Africa (e.g. de Meij and Lelieveld, 2011). Almost one-quarter of the natural AOD is attributed to biomass burning, which also occurred in pre-industrial times.

The spectral variation of AOD (Fig. S1 of Supplement) shows that there is a stronger dependence of AOD on wavelength for anthropogenic than natural aerosols. This is due to the size of the particles, with anthropogenic (fine) aerosols being weak absorbers of near-infrared radiation, as opposed to natural (coarse) aerosols whose size is closer to infrared 
Table 2. Total mid-visible $(550 \mathrm{~nm})$ aerosol optical depth (AOD) for HAC and MODIS, and their absolute and relative differences. The values in brackets are for common HAC-MODIS pixels.

\begin{tabular}{lrrrr}
\hline Aerosol optical depth (550nm) & HAC & MODIS & HAC-MODIS & (HAC-MODIS)/MODIS (\%) \\
\hline ANNUAL GLOBAL & $0.130(0.132)$ & 0.159 & $-0.029(-0.027)$ & $-18.2(-17.0)$ \\
ANNUAL N. HEMISPHERE & $0.163(0.160)$ & 0.191 & $-0.028(-0.031)$ & $-14.7(-16.2)$ \\
ANNUAL S. HEMISPHERE & $0.097(0.102)$ & 0.123 & $-0.026(-0.021)$ & $-21.1(-17.1)$ \\
LAND AREAS ONLY (common pixels) & $(0.190)$ & 0.209 & -0.019 & -9.1 \\
OCEAN AREAS ONLY (common pixels) & $(0.118)$ & 0.149 & -0.031 & -20.1 \\
WINTER (DJF) & $0.117(0.121)$ & 0.146 & $-0.029(-0.025)$ & $-19.9(-17.1)$ \\
SPRING (MAM) & $0.137(0.137)$ & 0.168 & $-0.031(-0.031)$ & $-18.5(-18.5)$ \\
SUMMER (JJA) & $0.144(0.145)$ & 0.167 & $-0.023(-0.022)$ & $-13.8(-13.2)$ \\
AUTUMN (SON) & $0.123(0.124)$ & 0.154 & $-0.031(-0.030)$ & $-20.1(-19.5)$ \\
\hline
\end{tabular}

radiation wavelengths and therefore more efficient in absorption throughout the solar spectrum.

\subsection{MODIS}

HAC AOD is compared to monthly Level 3 MODIS Collection 5 (C005, Remer et al., 2005; Levy et al., 2007a, b) data from March 2000 to February 2007. The use of MODIS here is due to the fact that MODIS products have been extensively validated and regarded as the most reliable global satellite AOD datasets to date, as shown by various validation studies against reference AERONET data (e.g. Levy et al., 2010; Remer et al., 2005; Ichoku et al., 2002; Chu et al., 2002). The Deep Blue MODIS datasets could also be potentially used, but due to their limited validation to date they were not used in the present study. MODIS sensors on the Terra and Aqua satellites observe aerosols over land and ocean in a variety of spectral bands, from blue to thermal infrared (Kaufman et al., 1997; Remer et al., 2005), every 1-2 days with a 16-day repeat cycle. The expected error in MODIS-derived AOD values over land, based on overpass events over AERONET sites, is $\pm(0.05+0.20 \times$ AOD) for Collection 5 (Levy et al., 2010), whilst the pre-launch uncertainty in AOD over ocean was $\pm(0.05+0.05 \times$ AOD) (Remer et al., 2002).

Remote sensing of aerosol optical properties from a satellite highly depends on the wavelength of the reflected solar radiation and the reflectivity of the surface. Maximum sensitivity to aerosol optical depth occurs over surfaces with low reflectance, such as ocean surfaces or dark land surfaces (King et al., 1999). On the other hand, for brighter surfaces, such as deserts and ice sheets, aerosol retrievals are more difficult, resulting in missing values for several months and for certain locations in MODIS C005. In presenting MODIS AOD data from several years, there is a trade-off between the more appropriate temporal representation and the more appropriate spatial representation. We have chosen to use the following criterion in order to plot the maps that will be used for the comparison: for each season of each year, at least 2 out of the 3 months of the period should be available. Then for each year, the annual mean value has been calculated and presented only when all 4 seasons were available. Finally, for the mean values of the whole period, at least 3 out of 7 annual values were required.

Levy et al. (2010) thoroughly assessed the performance of the aerosol products over dark-land targets by using a new algorithm. Their analysis demonstrates that the MODIS AOD retrieval often picks incorrect aerosol compositions, which biases the retrieved AOD values. Other biases are introduced by nearby clouds (e.g. 3-D effects, shadowing or misinterpretation). When the cloud fraction is greater than $20 \%$, the mean MODIS overestimation approaches $0.03-0.04$ or $15-$ $20 \%$ in addition to the uncertainty that arises due to the surface type (Levy et al., 2010). Thus, users of MODIS AOD products need to be aware of retrieval limitations and possible biases. Due to better constrained surface properties over glint-free deep oceans, aerosol retrievals over oceans are generally more reliable than over land (Levy et al., 2010). With larger uncertainties over land, MODIS even has slightly negative values over such areas.

\subsection{CALIOP}

The CALIPSO satellite was launched in April 2006 with its main objective being to provide the scientific community with global, day and night data of the vertical distribution of cloud and aerosol optical and spatial properties (Winker et al., 2007). The primary payload of the CALIPSO satellite is a two-wavelength and polarization-sensitive elastic backscatter lidar, the CALIOP instrument. An extensive discussion on the uncertainties in the CALIOP calibration is found in Powell et al. (2009), where it is mentioned that calibration is expected to have a bias no larger than $5 \%$. Version 3.01 (released in May 2010) performs better than version 2 in daytime retrievals. Night-time performance is essentially the same, as night-time calibration procedures were unchanged in version 3.01 (Rogers et al., 2011). In clear-sky conditions, Mona et al. (2009) found CALIOP to bias slightly low $(-2 \pm 12 \%)$ in the free troposphere $(3-8 \mathrm{~km})$ and very low $(-24 \pm 20 \%)$ in the planetary boundary layer (PBL, below $2.5 \mathrm{~km})$. While there was large confidence for the small bias 
at high altitudes, this was not the case with the large bias in the PBL due to the large distance between CALIOP and the ground-based lidar. Rogers et al. (2011) found good agreement between aircraft and CALIOP $532 \mathrm{~nm}$ total attenuated backscatter inside the PBL (below $\sim 3 \mathrm{~km}$ ). One of the weaknesses of the CALIOP retrieval process is the misinterpretation of heavy aerosol loads (i.e. desert dust over West Africa) as clouds, especially during daytime due to low signal-tonoise ratio (Pappalardo et al., 2010; Pappas et al., 2013).

The CALIOP version 3 data, which are used here as reference for the AOD vertical distribution, have matured through increasing validation against surface-based lidar measurements, e.g. EARLINET (European Aerosol Research Lidar Network) and NIES (National Institute for Environmental Studies, Japan). The data that we used here cover the period from July 2006 to January 2011. The vertical resolution of CALIOP varies according to the altitude, being $30 \mathrm{~m}$ for altitudes between 0.5 and about $8.2 \mathrm{~km}$ and $60 \mathrm{~m}$ for altidudes from about 8.2 to about $20.2 \mathrm{~km}$. Vertical information has been assigned to 200 vertical layers of $100 \mathrm{~m}$ thickness each. Layers are then clustered accordingly, so that they match the vertical layers provided by HAC. In terms of data quality screening, one of the retrieval confidence measures is the CAD (cloud-aerosol discrimination) score. In our study, we have used a threshold CAD score smaller than -50 , which removes most of the dubious retrievals. CALIOP is a polarorbiting satellite with a period of around 16 days. Therefore, the representativeness of its retrievals is not always ideal, and retrievals need to be used with due care.

\section{Evaluation of HAC aerosol optical depth (AOD)}

\subsection{Regional patterns}

The comparison between HAC and MODIS AOD on a global and hemispherical basis (Table 2) shows overall lower AOD values for HAC. The HAC annual global AOD value at $550 \mathrm{~nm}$ (Fig. 1a) is 0.130 , smaller than for MODIS (0.159, global distribution shown in Fig. S3, Supplement) by $-18.2 \%$. Takemura et al. (2002) used a global threedimensional model and found an annual global AOD equal to 0.116 , while Ramanathan et al. (2001) reported a value of $0.12 \pm 0.04$. When averaging HAC on the basis of common pixels with MODIS, AOD slightly increases to 0.132 (Table 2), still lower than MODIS (by $-14.7 \%$ ). According to HAC, there is a strong inter-hemispherical asymmetry in terms of AOD, with the values for the $\mathrm{NH}$ being almost double that for the SH (ratio equal to 1.68). Such a contrast is also found in MODIS with a ratio of 1.55. The annual relative AOD difference between common HAC and MODIS pixels is slightly smaller for the $\mathrm{NH}(-16.2 \%)$ than for the SH $(-17.1 \%)$. The biases are similar and since there is a large contrast in the hemispherical aerosol load, the biases are not dependent on aerosol load. However, the larger
MODIS AOD value (of 0.123 compared to 0.097 by HAC) for the SH likely reflects a positive MODIS bias, due to poor cloud screening over the southern oceans.

In order to better assess the HAC-MODIS differences, the AOD values (at $550 \mathrm{~nm}$ ) were also compared separately over land and over ocean. The MODIS AOD value (0.209) over land agrees very well with the corresponding value $(0.203)$ provided by Levy et al. (2010). For the same period used in this study, Remer et al. (2008) found a global over-land value of 0.19 in both Aqua and Terra. For the global land, including global deserts (not covered by MODIS here), Yu et al. (2006) refer to published Multi-angle Imaging SpectroRadiometer (MISR) data that yield a mean AOD value of $0.23 \pm 0.05$. Note also that sampling frequency, and hence reliability, is larger for MODIS than for MISR. For the global ocean, the MODIS value computed here is 0.149 , close to the range of values found in the literature (e.g. 0.13-0.14 by Yu et al., 2006, and Remer et al., 2008). It appears that HAC AOD values $(0.19$ and 0.118 for land and ocean, respectively, Table 2) are closer to MODIS retrievals over land areas (bias equal to $-9.1 \%$ ), which are more abundant in the $\mathrm{NH}$, while the agreement is not as good over oceanic areas (bias of $-20.1 \%$ ), which are dominant in the SH. However, there are many issues on the accuracy of MODIS retrievals reported in the literature (e.g. Papadimas et al., 2009; Levy et al., 2010; Zhang and Reid, 2010). For example, Zhang and Reid (2010) have made an extensive study on the various versions of MODIS products, and one of their findings was that the increased Level 3 AOD over the Southern Ocean is mostly caused by cloud contamination. This explains part of the differences between HAC and MODIS AOD for the SH. It has been reported in several studies that lower AOD values (i.e. over oceans) are biased high by MODIS, while the higher AOD values, over land, are biased low (Remer et al., 2005; Levy et al., 2005). Another issue is the MODIS AOD overestimation of fine-mode aerosol by about 0.02 (Levy et al., 2010), which could account largely for the NH differences (Table 2).

Since the accuracy of MODIS retrievals largely depends on the type of surface (Levy et al., 2010), a closer look into regional patterns would enable us to draw further conclusions on the accuracy of HAC AOD values, taking into consideration the possible errors in MODIS retrievals and discussing them in the context of the relevant literature. The study of Levy et al. (2010) was based on specific sites and not on whole regions, so the selection of the sites could cause biases with regards to the general trend for whole regions. However, due to the fact that there are certain areas with a homogeneous profile of aerosol load, a projection from individual sites to larger areas could be justified. AOD differences are not systematic, having both a positive and a negative sign (Fig. 2). The areas with larger HAC AODs are mostly land areas with high aerosol load, either due to pollution (eastern Europe, east coast of United States and East Asia), due to desert dust (the coast off N. Africa, Gobi Desert, the coast off 
(a)
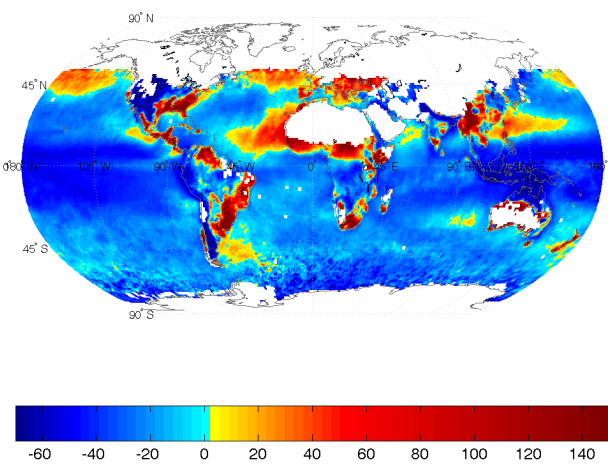

(c)
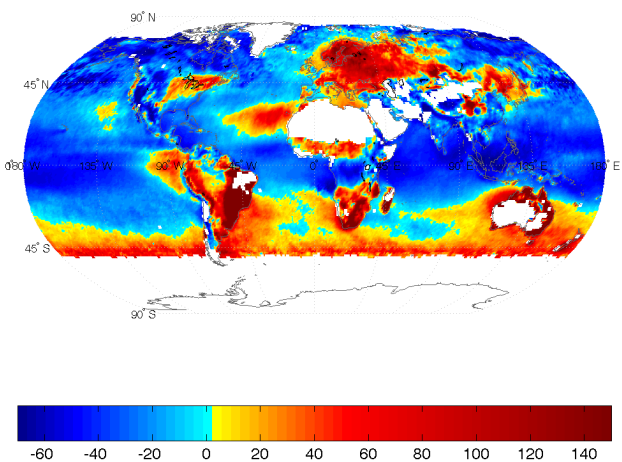

(b)
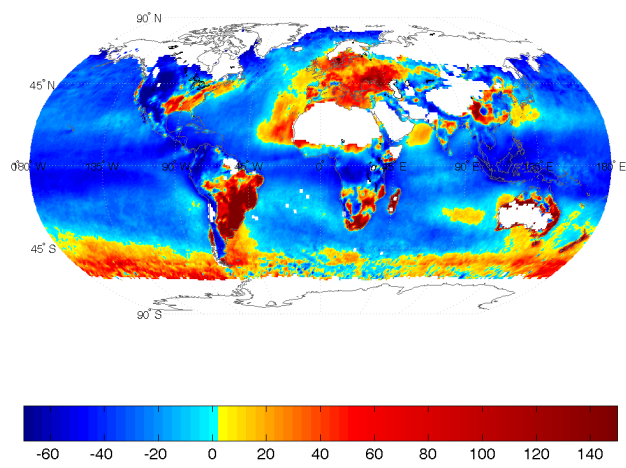

(d)
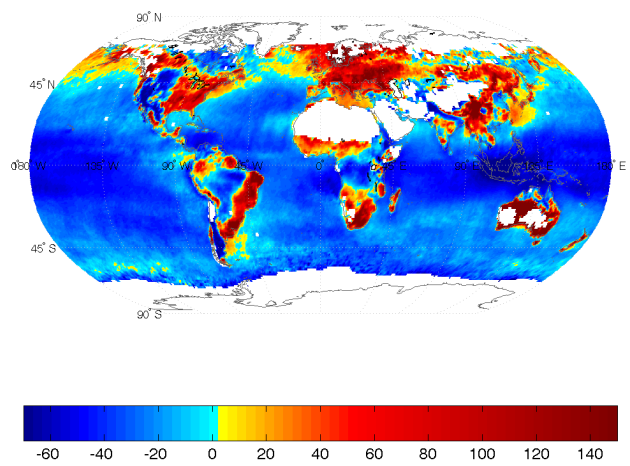

Fig. 2. Comparison between HAC and MODIS (03/2000-02/2007) total aerosol optical depth at $550 \mathrm{~nm}$. Global seasonal distribution of relative percentage differences ((HAC-MODIS)/MODIS - \%) for (a) winter (DJF), (b) spring (MAM), (c) summer (JJA) and (d) autumn (SON). White shaded areas correspond to cases for which MODIS AOD values are missing or do not qualify for the averaging threshold. The maps are presented on a $1^{\circ} \times 1^{\circ}$ latitude - longitude resolution.

West Africa), or due to biomass burning smoke (east coast of S. America and the area of S. Africa). In some cases, part of those discrepancies can be attributed to MODIS biases. For instance, reported MODIS low bias over biomass burning areas, such as the African Sahel (Levy et al., 2010), partly offsets the larger HAC AOD values (Fig. 2a, c, d). On the other hand, MODIS is shown previously to overestimate slightly AOD compared to ground-based AERONET network values by 0.05 or $60 \%$ over areas with fine aerosol, like eastern United States (Levy et al., 2010) and by significantly more when desert dust is present (Levy et al., 2003, for $550 \mathrm{~nm}$ ). HAC values are larger in the above-mentioned areas (Fig. 2), so it appears that there might be a high bias for fine-mode aerosols and dust also. On the other hand, there are land areas, such as western USA, central Africa and India, where HAC AOD values are smaller than MODIS. This can be explained by the fact that MODIS tends to overestimate AOD over surfaces that are brighter and less green than optimal, like central Africa or western USA (Levy et al., 2010).

Over ocean, HAC AOD values are consistently lower than MODIS by up to about $60 \%$, especially in the tropics. However, during NH summer and for the upper part of the southern windy zone, HAC reports higher AOD values by up to $70-80 \%$. This situation, which is also observed in $\mathrm{NH}$ spring but to a smaller extent, is reversed during $\mathrm{NH}$ autumn and winter, probably due to misclassification of sub-pixel clouds as coarse aerosol by MODIS (Fig. S3, Supplement). It is interesting to note that larger values of HAC are found over oceanic areas undergoing dust export (e.g. over the northern tropical Atlantic Ocean, where it is possible that MODIS misidentifies heavy dust events as clouds). In general, HAC seems to agree better with MODIS over land than ocean (especially in the $\mathrm{NH}$ ) verifying thus the conclusions drawn from the results of Table 2 . 


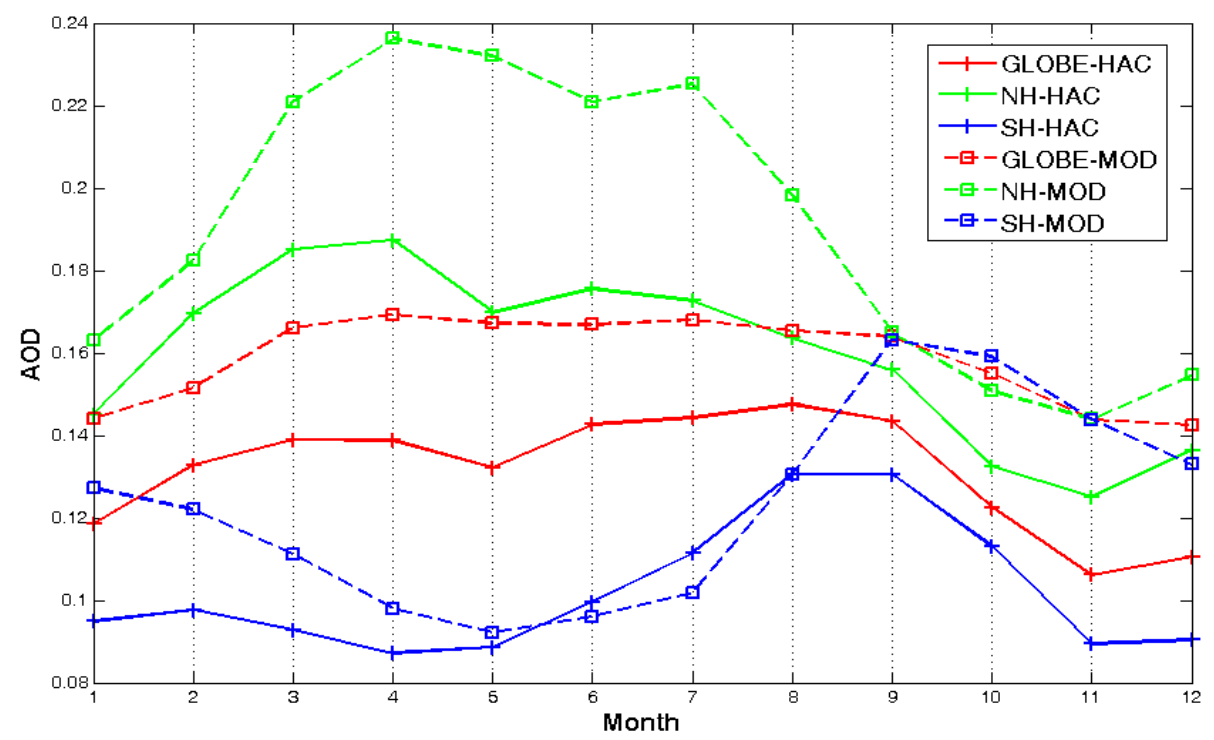

(a)

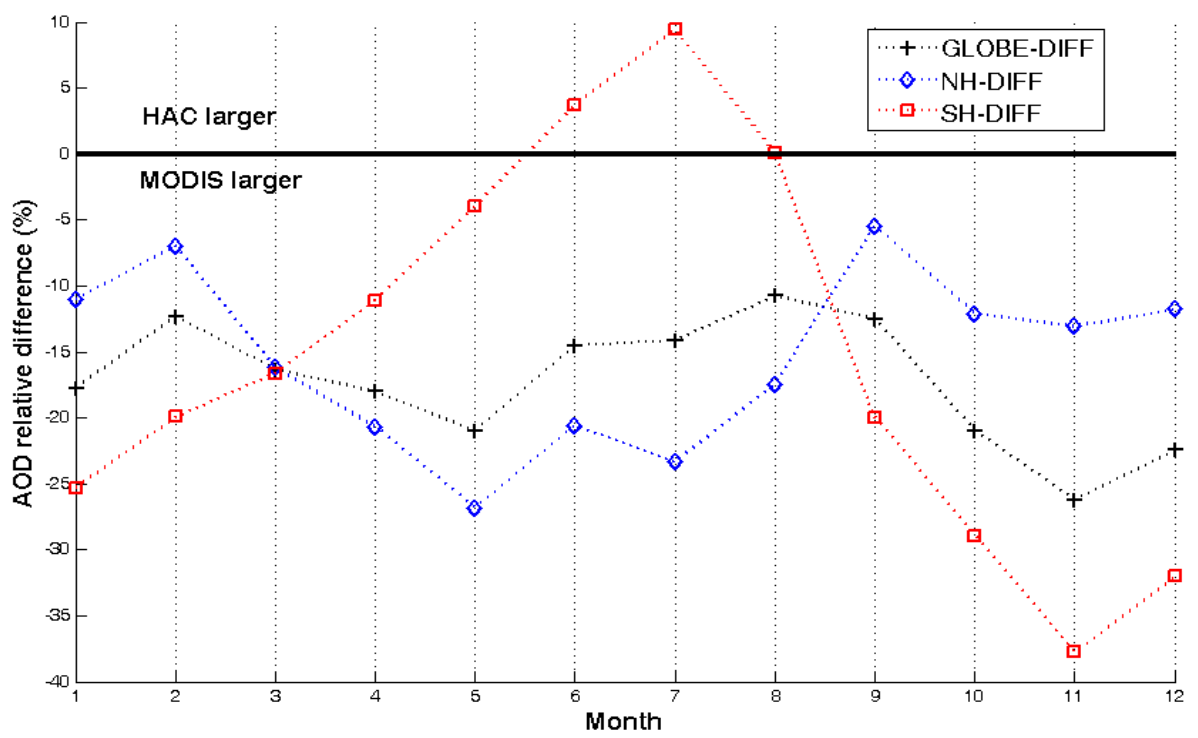

(b)

Fig. 3. Intra-annual variation of (a) HAC and MODIS global and hemispherical monthly AOD and (b) HAC and MODIS global and hemispherical monthly AOD relative differences ((HAC-MODIS)/MODIS). Note the negative scale on $y$ axis in Fig. 3b. Values are for common grids.

\subsection{Seasonal patterns}

The seasonal variation of global and hemispherical averages of HAC and MODIS AOD (Fig. 3a and Table 2) reveals that there are certain similarities and differences in the annual cycle. Global HAC AOD values are systematically lower than MODIS ones throughout the year (Fig. 3b), with HACMODIS (relative) differences reaching values of $-20.1 \%$ and $-19.9 \%$ in the boreal autumn and winter, decreasing to $-13.8 \%$ in summer (JJA, yellowish and reddish colours in Fig. 2c and Table 2), due to the larger HAC AOD values over the Southern Ocean. A more thorough look reveals certain differences between the two datasets. Thus, while the MODIS highest values appear during NH spring $(0.168)$ and summer (0.167), for HAC NH spring values reach 0.137 , while in summer (JJA) they peak at 0.144 (i.e. they are larger than spring values by about $5 \%$ ). The global mean HAC AOD values show a minimum in May (Fig. 3a), which is not so distinct in MODIS data. From the monthly HAC plots (not shown here), the following appears during May in HAC: (a) the desert dust AOD over Saudi Arabia is reduced, relative to 
April and June plots; (b) the dust transport from West Africa over the Atlantic Ocean is also reduced; and (c) there is significantly reduced AOD in the far north-west corner of the Pacific Ocean, again due to reduced transport of aerosol from East Asia. The hemispherical AOD differences reveal that the largest global HAC-MODIS AOD differences arise from the largest deviations in the SH during austral spring (OctoberNovember) and summer (DJF). SH difference is positive in summer (JJA) due to biomass burning and Southern Ocean larger HAC values. The results of Fig. $3 \mathrm{~b}$ prove that any assessment of AOD differences between the two databases has to be made on a hemispherical or even better on a regional rather than on a global scale, since the sign of the difference is mixed. Possible reasons for these differences could be biases of the model-dependent background of the HAC involving model input (e.g. emissions, meteorology) and aerosol processing (e.g. transport and removal) or biases in assumptions for aerosol composition and environment in MODIS AOD retrievals.

A characteristic example of the biases in MODIS AOD retrievals is the case of biomass burning areas. The seasonal plots (Fig. 2a-d) show that there is a non-uniform pattern over the Amazon Basin. During NH summer, HAC AOD is larger than MODIS AOD in the southern and eastern parts of the Amazon Basin, while the sign is opposite in the northern and western parts of the basin. On the other hand, during the NH spring, autumn and winter, HAC AOD is smaller than MODIS AOD over the largest part of the basin. For JJA, Levy et al. (2010) found a high bias in MODIS over certain parts of the area (i.e. Alta Floresta in their Fig. 4). This justifies the negative values seen in part of the area (Fig. 2c). The missing grids in the region in $\mathrm{NH}$ spring and summer plots are most likely due to large cloud cover or zero values of MODIS that have been artificially excluded from the plots. Missing grid cells in all plots are due to our criterion for representativeness of each season in the annual mean. Comparing Figs. 2 and S3 of the Supplement (showing seasonal global distributions of MODIS AOD), it is evident that those missing grid cells are due to the exclusion of MODIS information because of the application of our strict criterion on data availability (see Sect. 2.2). Most missing grid cells are during winter (DJF) when a large part of the $\mathrm{NH}$ land areas is covered by clouds and snow, making retrieval from MODIS impossible. Misinterpretation of biomass burning smoke as clouds by MODIS over North Australia is responsible for smaller HAC AOD values in the local dry season (no biomass burning), but they are larger during the wet season by up to more than $40 \%$.

The overall comparison between HAC and MODIS AOD is given in the scatter plots of Fig. 4, where monthly values for all grid cells at $1^{\circ} \times 1^{\circ}$ latitude-longitude resolution have been used. On an annual basis, there is a relatively good agreement between the two datasets, yielding a correlation coefficient $(R)$ equal to 0.76 for $\mathrm{NH}$ and 0.66 for $\mathrm{SH}$ and a root mean square error (RMSE) of 0.072 and 0.043 for $\mathrm{NH}$ and SH, respectively. Seasonally, for $\mathrm{NH}$, the worst fit, in terms of $R$ values, is found in boreal autumn (Fig 4e). Nevertheless, if we except the lowest correlation coefficient $(R=0.68)$, the autumn bias $(-0.01)$ and RMSE (0.069) are the smallest, indicating a very good agreement. The largest bias for $\mathrm{NH}$ is in spring (bias $=-0.046$, $\mathrm{RMSE}=0.092$ ). Spring and summer have the worst agreement between HAC and MODIS, probably due to desert dust misinterpretation by MODIS. On the other hand, autumn and winter have a better agreement. For the $\mathrm{SH}$, boreal spring and autumn have the worst fit $(R=0.47)$ and largest bias $(-0.041)$, respectively. The former is likely to be due to the erroneous MODIS retrievals for the Southern Ocean and the latter due to misinterpretation of biomass burning events as clouds. The only positive bias (0.001) of HAC is found in summer (JJA) for $\mathrm{SH}$, in agreement with the larger oceanic values mentioned earlier (Fig. 2c).

\section{Spectral validation of AOD}

Aerosol optical properties exhibit significant variation with wavelength. Knowledge of aerosol optical properties on several wavelengths and for different parts of the electromagnetic spectrum can be useful to identify different aerosol sizes and possibly types (Vardavas and Taylor, 2011). Broadband radiative transfer simulation and climate models need to cover the entire solar spectral range (extending at least up to $5000 \mathrm{~nm}$ ) and beyond that up to the terrestrial far infrared in terms of aerosol optical properties (Hatzianastassiou et al., 2004b). One of the great advantages of the new aerosol HAC dataset is that it provides aerosol data with a large spectral coverage. Here we attempt to evaluate the HAC spectral AOD profile by comparing it against MODIS and ground-based AERONET station values. MODIS aerosol models are not totally independent of AERONET measurements, as they are used for validating, correcting and improving satellite retrievals ("Algorithm for Remote Sensing of Tropospheric Aerosol from MODIS", ATBD-MOD-02; http: //modis.gsfc.nasa.gov/data/atbd/atmos_atbd.php). HAC data are not totally independent either, since AERONET station statistics were initially used to modify the modelling background in the process of building HAC. However, local details for individual stations are not kept in the final result. Hence, differences are expected between the two datasets. AERONET data from 1998 to 2007 (from 2001 for Jabiru and from 1999 for Tahiti) and for the months of January (April for Dalanzadgad) and July (September for Alta Floresta) have been used for certain representative grids that correspond to the main aerosol types: (a) desert dust, (b) marine, (c) biomass burning and (d) urban. The five (5) sites that were selected are seen in Fig. 5. Based on the availability of AERONET and MODIS data, the spectral comparison is necessarily restrained in the range from $300 \mathrm{~nm}$ to $700 \mathrm{~nm}$ for continental sites, and from $300 \mathrm{~nm}$ to $2500 \mathrm{~nm}$ for oceanic 
(a)

\begin{tabular}{|c|}
\hline $\begin{array}{l}\text { North hemisphere: } \\
A E R_{A O D}=0.69^{\prime} \mathrm{MOD}_{A O D}+0.03 \\
\mathrm{R}=0.762 \\
\mathrm{RMSE}=0.0722 \\
\text { Bias }=0.0292 \\
\text { Mean } A E R_{A O D}=0.1608 \\
\text { Mean } M O D_{A O D}=0.1900 \\
\mathrm{~N}=19912\end{array}$ \\
\hline $\begin{array}{l}\text { South hemisphere: } \\
A E R_{A O D}=0.48^{7} \mathrm{MOD}_{\mathrm{AOD}}+0.05 \\
\mathrm{R}=0.660 \\
\mathrm{RMSE}=0.0430 \\
\text { Bias }=0.02028 \\
\text { Mean } A E R_{A O D}=0.1071 \\
\text { Mean } \mathrm{MOD}_{\mathrm{AOD}}=0.1288 \\
\mathrm{~N}=21838\end{array}$ \\
\hline
\end{tabular}

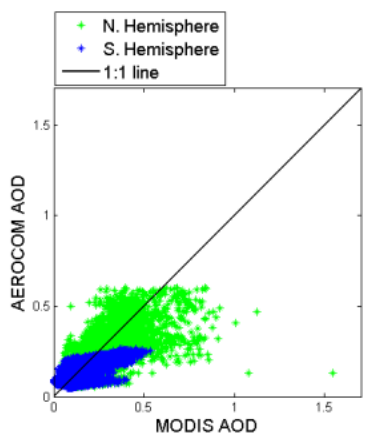

(b)

(c)

\begin{tabular}{|c|}
\hline 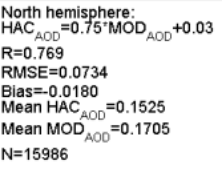 \\
\hline 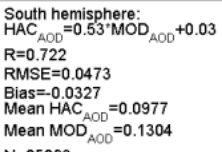 \\
\hline $\mathrm{N}=25263$ \\
\hline
\end{tabular}
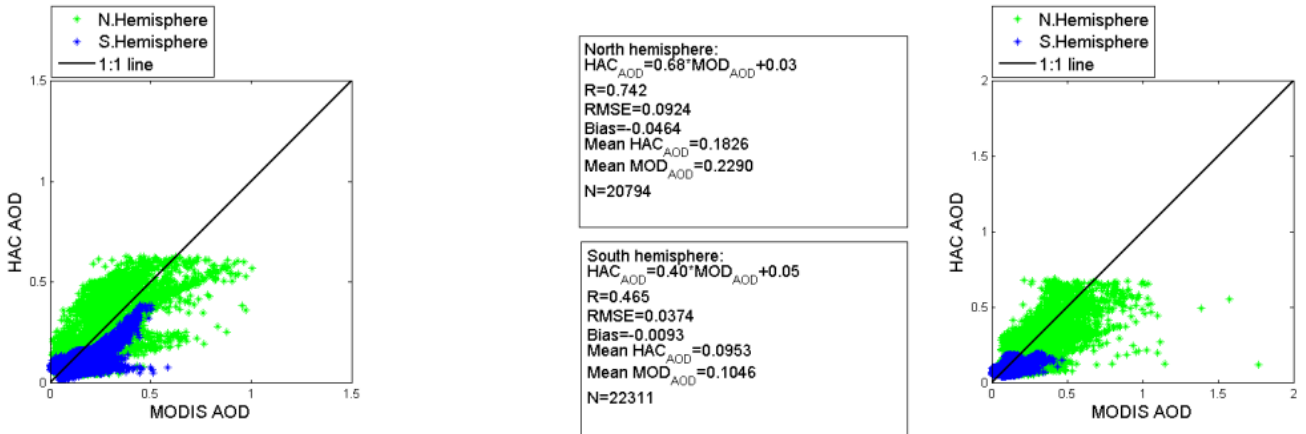

(d)

(e)
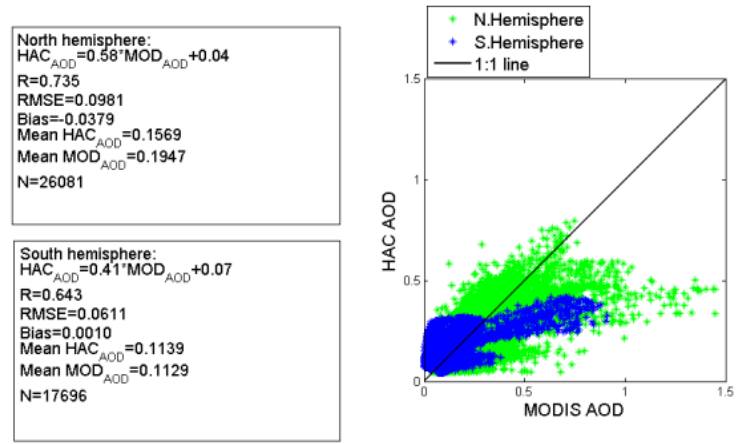

\begin{tabular}{|c|}
\hline $\begin{array}{l}\text { North hemisphere: } \\
H_{A A C_{A D}}=0.61^{\prime} \mathrm{MOD}_{A O D}+0.05 \\
\mathrm{R}=0.680 \\
\mathrm{RMSE}=0.0691 \\
\text { Bias }=0.0101 \\
\text { Mean } \mathrm{HAC}_{\mathrm{AOD}}=0.1336 \\
\text { Mean } \mathrm{MOD}_{\mathrm{AOO}}=0.1437 \\
\mathrm{~N}=22081\end{array}$ \\
\hline 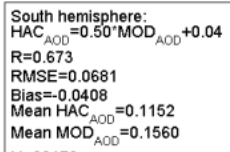 \\
\hline $\mathrm{N}=22478$ \\
\hline
\end{tabular}

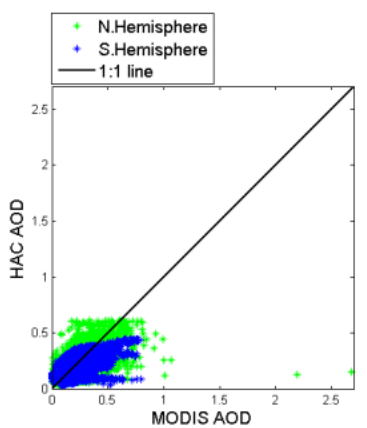

Fig. 4. Scatter plot comparison between total aerosol optical depth from HAC (AeroCom based) and MODIS datasets, for all months (a), and for DJF (b), MAM (c), JJA (d) and SON (e). Green points are for Northern Hemisphere and blue points for Southern Hemisphere. Black line in the plots is the $1: 1$ line. Statistics given in the text boxes in the plots separately for Northern Hemisphere and Southern Hemisphere are the correlation coefficients $(R)$, the root mean squared errors (RMSEs), the mean values (Mean), and the number of matched data pairs $(N)$. 


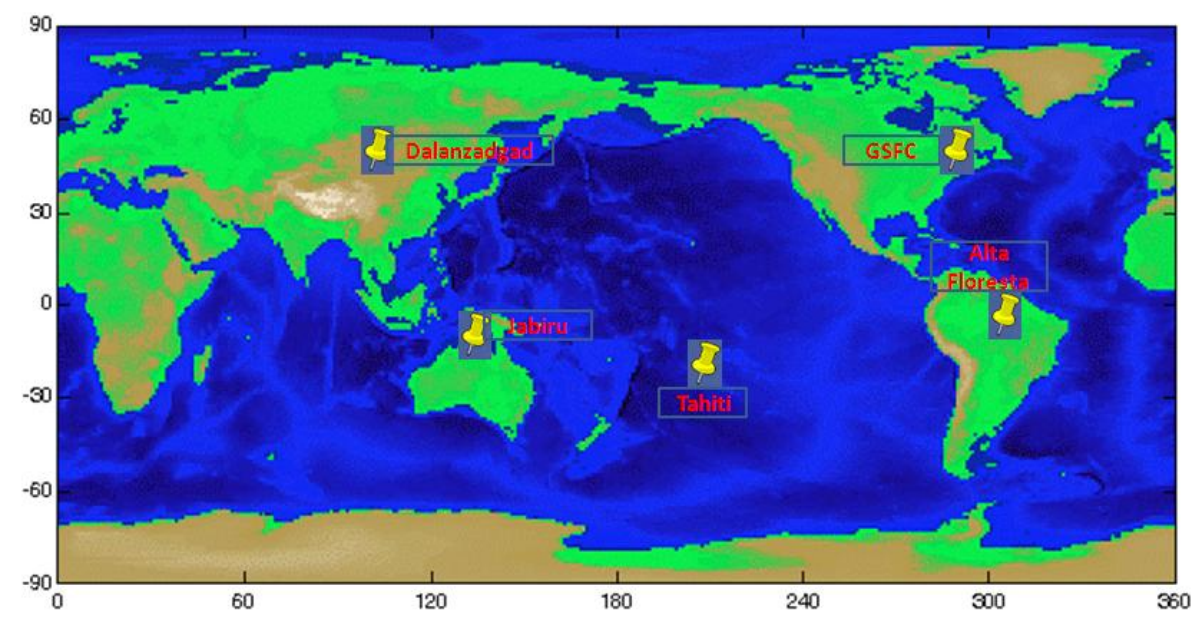

Fig. 5. World map with the five selected representative sites for which the spectral evaluation of HAC AOD is attempted: GSFC (1998-2007; $\left.38.99^{\circ} \mathrm{N}, 76.83^{\circ} \mathrm{W}\right)$, Alta Floresta (1999-2007; $\left.9.87^{\circ} \mathrm{S}, 56.10^{\circ} \mathrm{W}\right)$, Dalanzadgad (1998-2007; 43.57 $\left.{ }^{\circ} \mathrm{N}, 1^{\circ} 4.41^{\circ} \mathrm{E}\right)$, Jabiru $(2000-2007$; $\left.12.66^{\circ} \mathrm{S}, 132.89^{\circ} \mathrm{E}\right)$ and Tahiti $\left(1999-2007 ; 17.57^{\circ} \mathrm{S}, 149.60^{\circ} \mathrm{W}\right)$.

sites, for which spectral AOD data are available from all three databases.

The AERONET Goddard Space Flight Center (GSFC in Greenbelt, Maryland, USA) is a site located in a suburb of Washington, DC, with the urban aerosol type being dominant. In January (Fig. 6a-i), HAC AOD $550 \mathrm{~nm}(0.096)$ is equal to MODIS AOD $550 \mathrm{~nm}$, but larger than AERONET by $39 \%$. The spectral variation of both HAC and MODIS is in good agreement to AERONET except for UV. For the July plot (Fig. 6a-ii), HAC again captures the AERONET spectral variation quite well, having slightly larger AOD normalized AOD values in the UV and near-IR. The July value of HAC AOD at $550 \mathrm{~nm}$ is $0.308,20 \%$ smaller than AERONET and $27 \%$ smaller than MODIS. According to Kinne et al. (2012), the fine-mode aerosol is dominant in the UV. It appears that the fine-mode might be biased high in HAC, compared to AERONET observations. For the near-IR, coarse-mode particles are dominant. Although HAC correctly captures the seasonal increase in AOD, it might be that coarse-mode particles are overestimated.

For Alta Floresta (Amazonian Basin), a rural site directly influenced by smoke produced by biomass burning during the fire season (June to October), HAC AOD $_{550 \mathrm{~nm}}$ is smaller than AERONET and MODIS by $22 \%$ and $14 \%$, respectively, in January (Fig. 6b-i) and by $44 \%$ and $50 \%$, respectively, in September. HAC exhibits a stronger spectral decrease in the UV for both months which might be due to smaller particles assumed in HAC. The MODIS spectral profile is identical to HAC during January and identical to AERONET during September.

Dalanzadgad is a small city with a population of about 14000 at an altitude of $1470 \mathrm{~m}$ in the Gobi Desert in southern Mongolia. It is characterized by a typically cold desert climate with cold winters and hot summers. Here, the month of April has been used instead of January, as dust emission is at a maximum during April and spectral dependence is more important when AOD is high. Note that for April (Fig. 6ci) there are no MODIS data available over the area, possibly due to observational difficulties imposed by extended cloud coverage. Figure $6 \mathrm{c}$ reveals a stronger spectral dependence of HAC AOD than AERONET for the wavelengths smaller than $550 \mathrm{~nm}$. At those wavelengths, the larger contribution comes from fine-mode particles. As seen also at the GSFC site, it appears that fine-mode particles are overestimated in HAC. At larger wavelengths, the spectral variations are in good agreement. Looking at the absolute values of AOD at $550 \mathrm{~nm}$, both HAC and MODIS overestimate AOD compared to AERONET. This finding is in agreement with the study of Levy et al. (2010), who found that MODIS retrieval is biased high at this specific site. Eck et al. (2005) reported that AOD values remain relatively low all year with a monthly maximum of 0.20 in May and minimum of 0.05 to 0.06 (clean background levels) in December and January. HAC (and MODIS) overestimation, however, could be associated with the different spatial scales at which the spectral AOD data are reported in the three datasets and the strong spatial variability of AOD. Indeed, Kim et al. (2004) reported quite higher AOD values at Mandalgovi, which is also in Mongolia, about $275 \mathrm{~km}$ north-east of Dalanzadgad, with a longterm annual AOD mean of about 0.4 at $500 \mathrm{~nm}$, a value that is closer to that of HAC.

Jabiru is a savanna site in northern Australia, with complex aerosol composition consisting mainly of smoke from biomass burning and maritime aerosols (Qin and Mitchell, 2009; Grey et al., 2006; Hyer et al., 2011). In January (Fig. 6d-i), HAC AOD exhibits a stronger spectral dependence than MODIS and AERONET. There is better agreement between HAC and AERONET in July. In terms of 
(a-i)

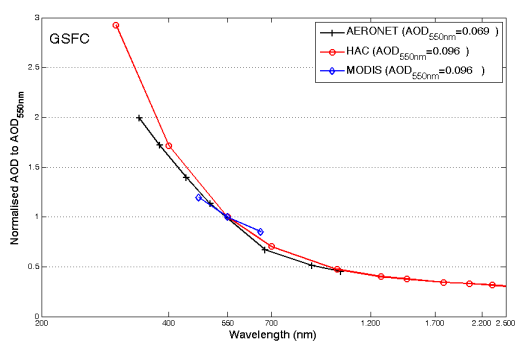

(b-i)

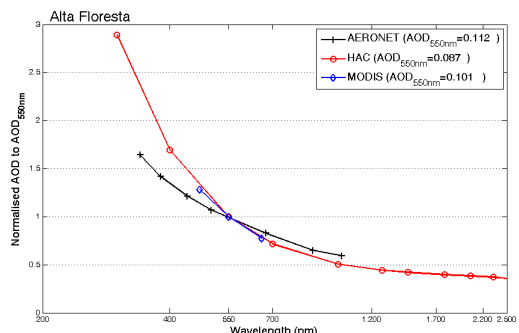

(c-i)

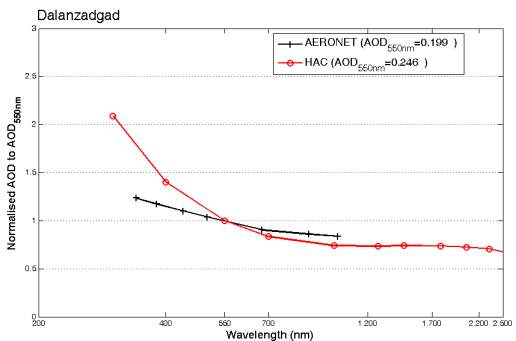

(d-i)

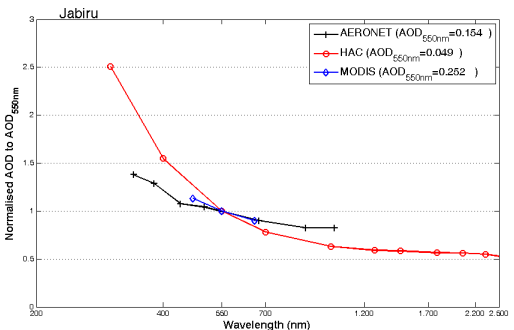

(e-i)

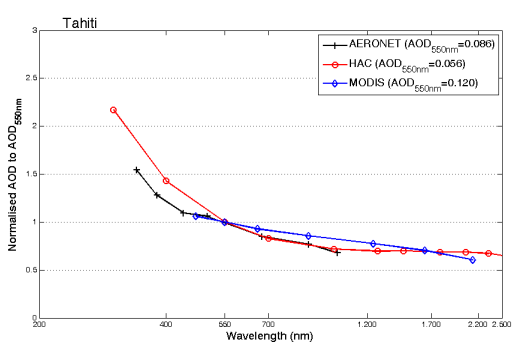

(a-ii)

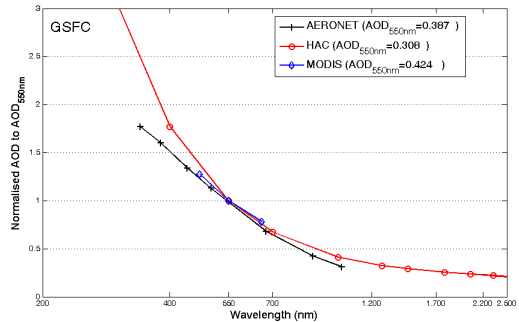

(b-ii)

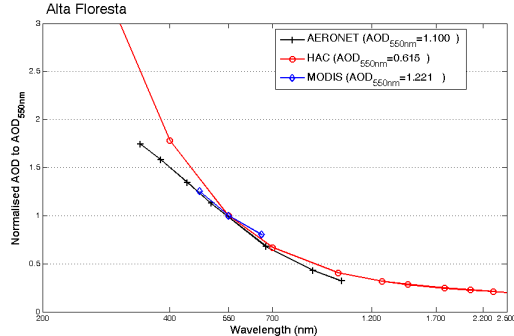

(c-ii)

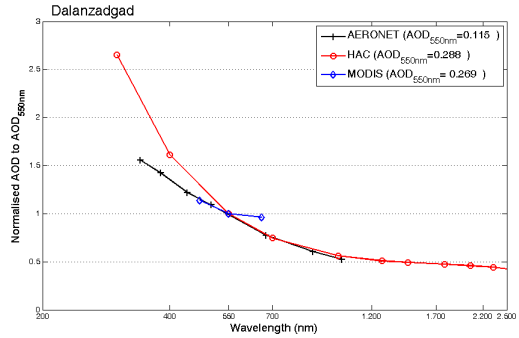

(d-ii)

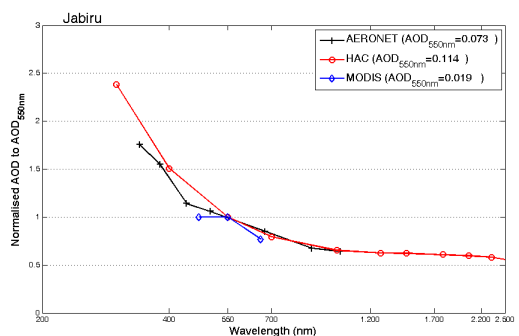

(e-ii)

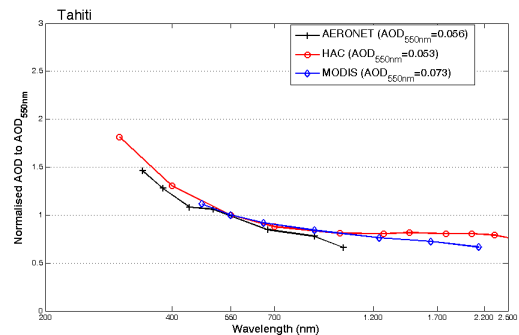

Fig. 6. Spectral profile of aerosol optical depth (AOD) and the differences between the three datasets over the five selected sites (see Fig. 5) for January (left column, all sites except Dalanzadgad, where April is shown) and July (right, all sites except Alta Floresta, where September is shown). Symbols and lines are as follows: solid black lines with plus signs for AERONET data, solid red lines with circles for HAC data, solid blue lines with diamonds for MODIS. The values on $y$ axes are AOD values normalized to the AOD value at $550 \mathrm{~nm}$. The legend boxes mention AOD for each dataset at $550 \mathrm{~nm}$. 


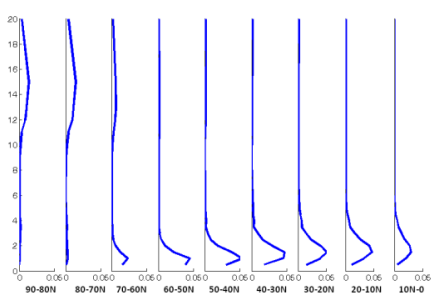

(a-i)

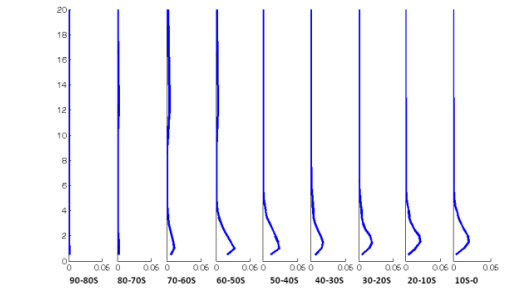

(b-i)

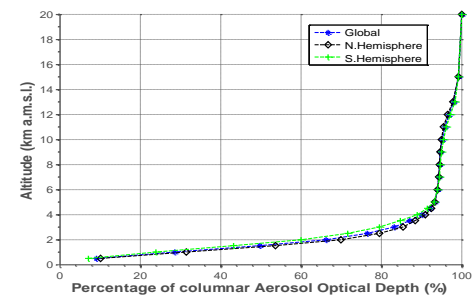

(c-i)

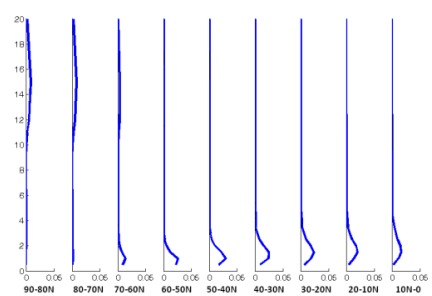

(a-ii)

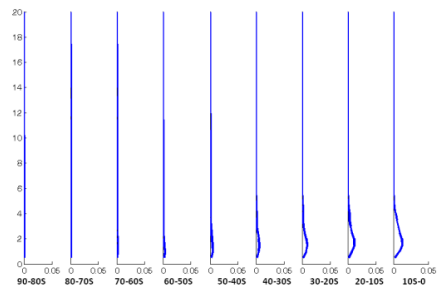

(b-ii)

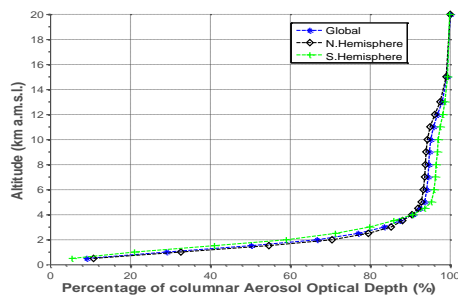

(c-ii)

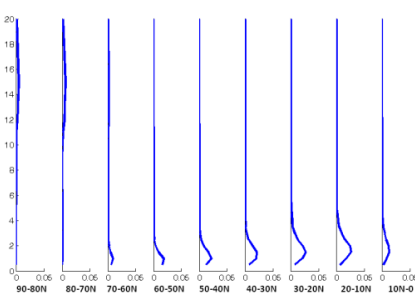

(a-iii)

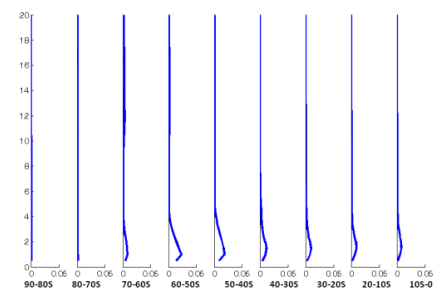

(b-iii)

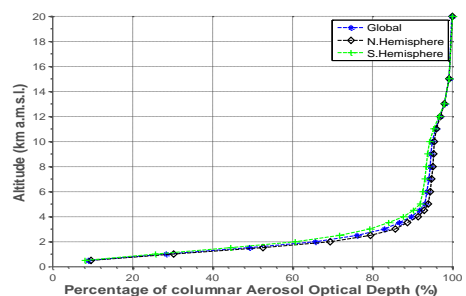

(c-iii)

Fig. 7. Vertical distribution of HAC AOD for total (left column, i), fine (middle column, ii) and coarse (right column, iii). HAC layer tops are at $0.5,1.0,1.5,2.0,2.5,3.0,3.5,4.0,4.5,5.0,6.0,7.0,8.0,9.0,10.0,11.0,12.0,13.0,15.0$, and $20.0 \mathrm{~km}$. Results are given in averages over 10-degree latitudinal zones of Northern Hemisphere (first row, a) and Southern Hemisphere (second row, b). In the third row (c), the cumulative fraction of columnar AOD (in \%) is given as function of altitude (in $\mathrm{km}$ ) averaged over the two hemispheres and the globe.

absolute values of AOD at $550 \mathrm{~nm}$, HAC has smaller values than AERONET and MODIS in January, but larger in July. Levy et al. (2010) found that MODIS retrieval is biased low in Jabiru.

For sites over ocean, MODIS provides AOD for the wavelength spectrum from 470 to $2130 \mathrm{~nm}$ and AERONET from 340 to $1020 \mathrm{~nm}$. The AOD values for Tahiti in the middle of the Pacific Ocean (Fig. 5) are low, as expected for clean maritime conditions (Smirnov et al., 2009). Sayer et al. (2010) give measured AERONET AOD values ranging from 0.03 to 0.07 at $550 \mathrm{~nm}$, in agreement with our HAC values. Although the spectral dependence at UV wavelengths seems to be slightly stronger in HAC, the spectral profiles of all datasets seem to converge at larger wavelengths.

\section{Vertical distribution}

Different vertical distributions of aerosols can yield variable results of radiative forcing and climate change, even if the columnar value of AOD is the same (Chung et al., 2010). In this section we attempt first to get a global picture of the aerosol vertical distribution based on HAC, and then to evaluate this vertical distribution with CALIOP space-borne lidar measurements. A detailed comparison between the HAC and CALIOP at global scale is beyond the scope of the present study. Therefore, we have chosen to perform a comparison only at regional and local scales. We perform the comparison for regions that are representative of various aerosol types, so we chose the Mediterranean basin and locations used in the previous section. The Mediterranean basin is a region with almost all types of aerosols coming from neighbouring natural and anthropogenic aerosol sources, both continental and maritime (Lelieveld et al., 2002). Thus, local emissions together with short- and long-range transport processes are expected to produce different vertical aerosol distributions.

HAC vertical distribution is based on the Hamburg Aerosol Module (HAM) within the ECHAM general circulation model. Figure 7 shows absolute HAC AOD values according to 20 pre-defined layers (top two rows) and the accumulated fraction of columnar AOD for fine, coarse and total aerosol for each altitude (bottom row). The computations/plots are made separately for $10^{\circ}$ latitudinal zones for both hemispheres, as well as hemispherically and globally, providing an overall picture of the vertical distribution of aerosols. The zonal means indicate that the vertical distribution of aerosols is not the same for the two hemispheres. 
In the $\mathrm{NH}$ the values of total (fine+coarse) AOD (i.e. the aerosol loads) for the lowest $5 \mathrm{~km}$ are similar for the latitudes $0-60^{\circ} \mathrm{N}$. Peaks are near $1.5-2.0 \mathrm{~km}$ and gradually decrease as we move from the Equator to higher latitudes. Despite the fact that significant AOD values are found up to $5 \mathrm{~km}$, most of the aerosol load is concentrated up to $3-4 \mathrm{~km}$. An interesting fact is that, for the zone $70-90^{\circ} \mathrm{N}$, a non negligible amount of aerosol is found at altitudes between 10 and $20 \mathrm{~km}$ (i.e. in the polar stratosphere) with a peak at around $15 \mathrm{~km}$ (AOD values per $\mathrm{km} \mathrm{0.0061-0.0146).} \mathrm{These} \mathrm{values}$ are in line (e.g. Matsui et al., 2011; Kondo et al., 2011) with observed aerosol transport from the northern mid-latitudes towards the Arctic. Such stratospheric aerosol amounts are not found in the SH polar latitudes. This is also verified by earlier (Stratospheric Aerosol Measurement - SAM2 - aboard Nimbus 7) and more recent satellite measurements (Stratospheric Aerosol Gas Experiment - SAGE-II, http://data.giss.nasa.gov/cgi-bin/sageii/sageii_v6.cgi) revealing higher stratospheric aerosol extinction over northern than southern high latitudes, with maximum during $\mathrm{NH}$ spring and summer (Treffeisen et al., 2006). In the SH, aerosols can be found above $10 \mathrm{~km}$ in the zones $50-70^{\circ} \mathrm{S}$, though with smaller AOD values than in the NH. The existence of aerosols at these high altitudes of the SH seems to be consistent with the reported long-range, even semi-global, transport of dust (Shaw, 1988), to Antarctica's clean environment. In the SH troposphere aerosols are lifted to slightly lower altitudes $(3-4 \mathrm{~km})$ than in the $\mathrm{NH}$ troposphere, confined to a shallower boundary layer as the SH is largely covered by oceans. Furthermore, according to HAC, the abundance of $\mathrm{SH}$ tropospheric aerosols is clearly reduced with respect to $\mathrm{NH}$ at all altitudes, with AOD not exceeding 0.028 per layer.

Globally, $50 \%$ of the total AOD is found up to a height of $1.50 \mathrm{~km}$ (Fig. 7c-i), and $85 \%$ of the total AOD is found from the surface up to $3.22 \mathrm{~km}$ above mean sea level (a.m.s.l.) with corresponding heights (for $85 \%$ ) equal to 2.96 and $3.52 \mathrm{~km}$ for $\mathrm{NH}$ and $\mathrm{SH}$, respectively. The vertical profiles of both fine and coarse aerosols are different for the two hemispheres, with fine aerosols being lifted slightly higher into the atmosphere in the SH than in the NH. Although the same is valid for coarse aerosols for the zones $30-70^{\circ}$ for both hemispheres, it is the opposite in the zone $0-30^{\circ}$, where coarse aerosols are lifted higher in the $\mathrm{NH}$ than in the $\mathrm{SH}$ (right column). The different behaviour of fine and coarse aerosols in the free troposphere above $4 \mathrm{~km}$ has to do with the location of their main source areas over the globe (Fig. S4b and c in the Supplement) in relation with the prevailing low or high pressure systems over or around them.

Aerosol vertical profiles are highly dependent on the season (e.g. Vuolo et al., 2009) and on the site location characteristics (i.e. above desert or ocean or urban area). In order to visualize this, we produced the accumulated fractions of columnar AOD as functions of height, for total aerosol, for the Mediterranean basin $\left(29.5-46.5^{\circ} \mathrm{N}, 10.5-36.5^{\circ} \mathrm{E}\right)$ for the months of January and July (Fig. 8a-i, ii). The profiles were produced using data from HAC and CALIOP. This comparison provides an idea of how aerosols are distributed vertically, regardless of the total columnar value. Nevertheless, note that differences already exist with regards to the latter. For instance, the mean HAC total columnar value for the entire Mediterranean region is 0.108 in January and 0.128 in July, while for CALIOP it is 0.083 and 0.172 , respectively, indicating a stronger seasonality in the CALIOP data. For the same area, MODIS columnar AOD data exhibit a seasonality similar to CALIOP, though at higher values $(0.116$ and 0.238 for January and July, respectively). The possible reasons behind the differences are as follows: (a) calibration and lidar ratio issues in CALIOP; (b) certain assimilation techniques followed when creating HAC dataset; (c) bias of CALIOP retrievals during overpass time with respect to AERONET or model which enable complete daily coverage; and (d) biases of ECHAM5-HAM model output. However, it is encouraging that the comparison of vertical distributions of AOD reveals relatively small differences between HAC and CALIOP. In January $50 \%$ (85\%) of columnar AOD in HAC is contributed by aerosols located below $1.2 \mathrm{~km}(2.1 \mathrm{~km})$, when the same fraction of AOD in CALIOP is contributed by aerosols below $1.1 \mathrm{~km}(2.5 \mathrm{~km})$. In July, the performance of HAC is even better. The largest difference occurs for the top $20 \%$ of columnar AOD, where HAC places it above $1.9 \mathrm{~km}$, while CALIOP detects it above $2.1 \mathrm{~km}$. For both datasets, aerosols are dispersed vertically at higher altitudes in July than in January, due to the thicker warmer boundary layer, and HAC successfully captures this for the whole column.

At the GSFC site (Figs. $8 \mathrm{~b}-\mathrm{i}$, ii), according to CALIOP retrievals, $50 \%$ ( $85 \%$ ) of columnar aerosol is located below $800 \mathrm{~m}(1350 \mathrm{~m})$ in January, while the same percentages for HAC are $1140 \mathrm{~m}(2100 \mathrm{~m})$. A similar pattern (i.e. placement of less HAC AOD in lower altitudes) is found in the July plot of GSFC. The misplacement here is around $500 \mathrm{~m}$ for the bottom $50 \%$ of AOD and decreases to $300 \mathrm{~m}$ for the bottom $85 \%$ of columnar AOD. CALIOP passes over the GSFC site at around 03:00 and 14:00 (local time) every day. As an average of all CALIOP retrievals has been used here, the night overpass is highly likely to bias results towards a less developed boundary layer and a more confined vertical dispersion.

For Alta Floresta (Figs. 8c-i, ii), the July plot corresponding to high monthly AOD (biomass burning season) shows good agreement up to $2.2 \mathrm{~km}$, while in the layers up to $5 \mathrm{~km}$ HAC places less aerosol than does CALIOP. The bottom $4 \mathrm{~km}$-thick layer includes $97 \%$ of HAC columnar AOD and $100 \%$ of CALIOP columnar AOD. The January plot, on the other hand, shows that HAC assumes a significantly smaller fraction of the columnar AOD in the boundary layer. Once more, this might be due to CALIOP overpass time (01:00 and 13:00 LT), whilst HAC dependence on AERONET might be more characteristic of a fully developed boundary layer.

HAC and CALIOP profiles are quite different for January in Dalanzadgad (Figs. 8d-i, ii), with HAC having a smaller gradient of decreasing AOD, especially above 

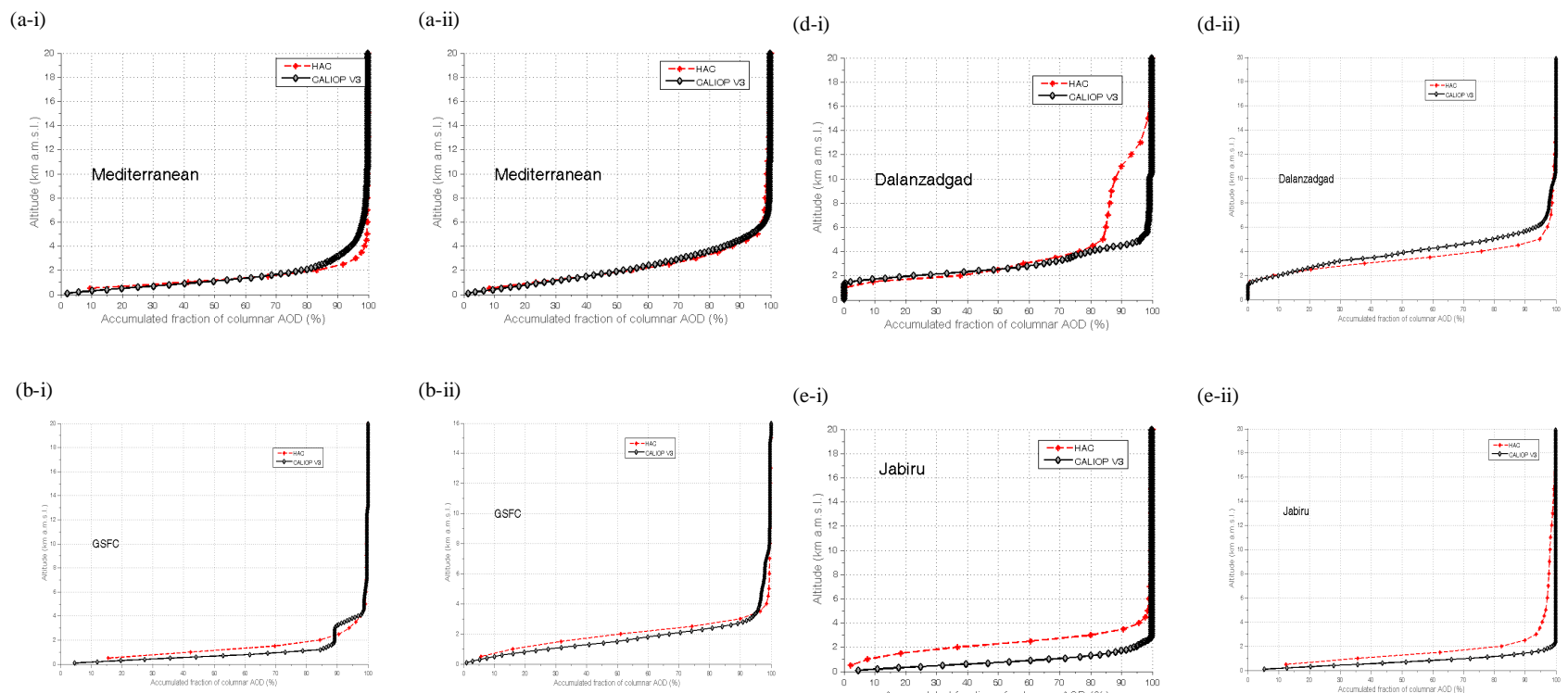

$(\mathrm{e}-\mathrm{i})$
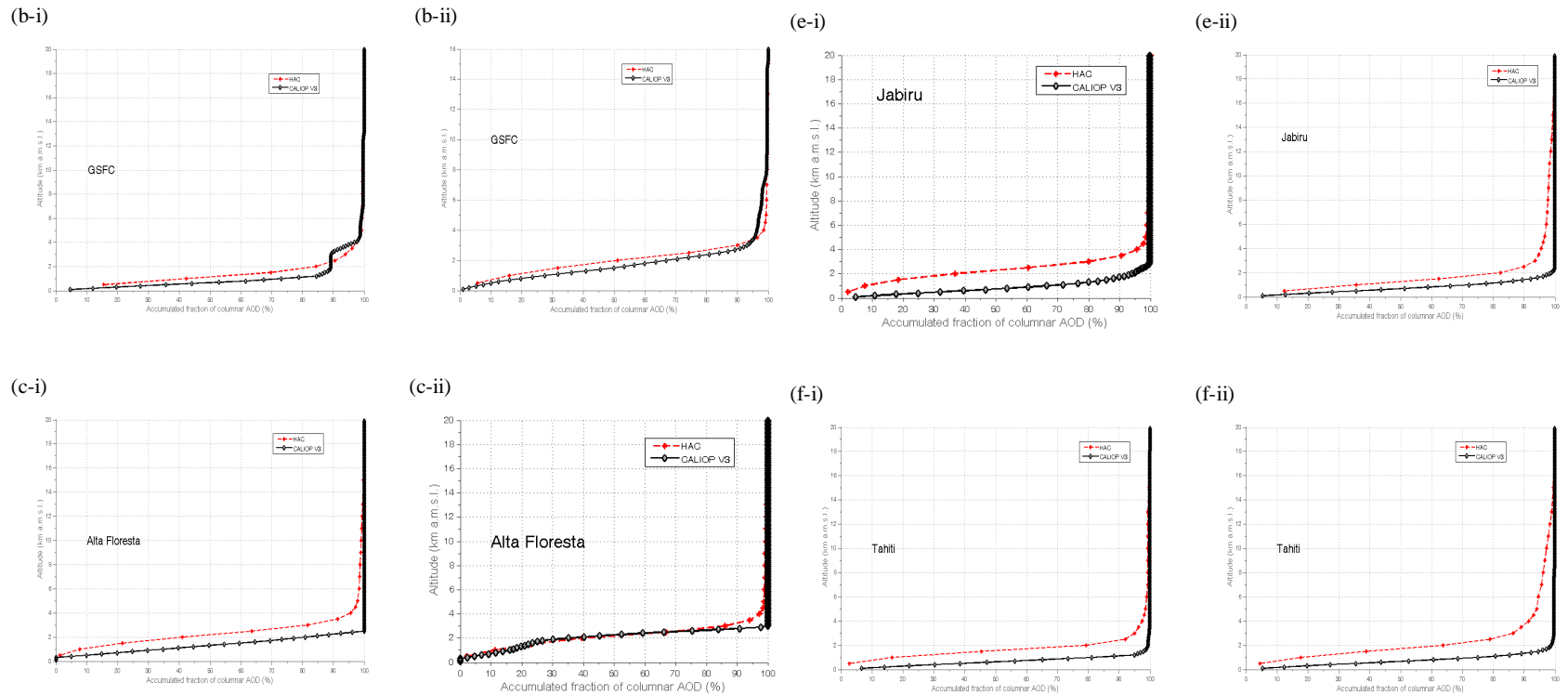

Fig. 8. Comparison between HAC (black lines and symbols) and CALIOP (red lines and symbols) vertical profiles of accumulated fractions of columnar total AOD. The comparison is made for the Mediterranean basin (a) and for the 5 selected world locations representative for specific aerosol regimes used in section 4: (b) GSFC, (c) Alta Floresta, (d) Dalanzadgad, (e) Jabiru and (f) Tahiti. Results are given separately for January (i) and July (ii), in each case. CALIOP values are for $532 \mathrm{~nm}$, while HAC values are for 550nm. Data for specific sites and for Mediterranean region are from July 2006 to January 2011.

$4.5 \mathrm{~km}$, indicating non-negligible amount of aerosol above that altitude. For the July plot, there is good agreement for the lowest $57 \%$ of aerosol column load. Above that, HAC has a smoother curve, indicating small amounts of aerosol in the upper layers, in contrast to CALIOP, which has a slightly sharper curve. For both months, desert dust that is lifted higher than the other types of aerosols is most likely the reason for $\mathrm{HAC}$ placing aerosols above $3 \mathrm{~km}$.

A high bias of aerosol altitude by HAC is seen in the plots for Jabiru (biomass burning and maritime aerosol type; Figs. 10e-i, ii) and Tahiti (oceanic aerosol type; Figs. 10f-i, ii). In Jabiru, the difference for the bottom $50 \%$ of columnar AOD is $1100 \mathrm{~m}(470 \mathrm{~m})$ for January (July). For July, HAC assumes significantly more aerosol in the upper layers (2$4 \mathrm{~km}$ ), while CALIOP has detected practically all aerosols $(95 \%)$ up to the altitude of $1.94 \mathrm{~km}$. While both datasets reflect the seasonal effect on convection and boundary layer height, this is more marked on the HAC dataset. The reason might again be the use of both daytime and night-time
CALIOP data, resulting in a shallower boundary layer and a limited vertical dispersion of aerosols.

In Tahiti, there is again a misplacement of aerosols by HAC for both January and July, placing the top $55 \%$ above $1.5-1.6 \mathrm{~km}$, while CALIOP has detected only $4.2 \%$ above that altitude. The vertical misplacement of aerosols from HAC ranges from about $550 \mathrm{~m}$ for the bottom $10 \%$ of columnar AOD to more than $1.1 \mathrm{~km}$ for the bottom $85 \%$. CALIPSO passes over the Tahiti site at 17:40 and 05:10 (local time) every day.

\section{Summary and conclusions}

The new Hamburg Aerosol Climatology (HAC) presented here is a mixture of ground-based AERONET observations and AeroCom model monthly median fields. It has been shown to reproduce well-known geographical and temporal features of aerosol load distributions successfully. Furthermore, it seems to yield adequately patterns associated with 
global distributions of anthropogenic and natural aerosols, with estimated contributions to the global average total AOD of 28.5 and $71.5 \%$, respectively. For the annual anthropogenic load, the largest contribution is during the NH summer and autumn by urban and industrial pollution. For the annual natural load, the largest contribution comes in the $\mathrm{NH}$ summer and spring due to desert dust with some contributions from natural wildfires.

A comparison has been attempted against multi-annual aerosol data retrieved from contemporary satellite sensors, namely MODIS and CALIOP. The comparisons have been performed for the mid-visible $(550 \mathrm{~nm})$ aerosol optical depth (AOD), as this is the aerosol optical property that quantifies the atmospheric aerosol load, with a large spatiotemporal variability, and always considered in radiative and climate models. In comparing HAC with MODIS collection 5 data (from March 2000 to February 2007) at $1^{\circ} \times 1^{\circ}$ (latitude/longitude) grid points, there were overall lower AOD values in the HAC. The HAC annual global mean total (natural plus anthropogenic) AOD is 0.132 , whereas the annual global mean for MODIS is 0.159 , thus larger by 0.027 or $17.0 \%$. Regionally, HAC has larger AOD values than MODIS in areas with heavy aerosol load, mainly over land (namely the northern subtropics), but smaller AOD than MODIS over ocean areas. An exception to that was the northern part of the Southern Ocean, where HAC yields larger values during $\mathrm{NH}$ spring and summer. HAC suggests $16.2 \%$ lower AOD than MODIS for the Northern Hemisphere and $17.1 \%$ lower AOD for the Southern Hemisphere. Therefore, the confidence in using HAC is the same for the whole globe. On a seasonal basis, HAC presents a summer (JJA) maximum (0.144), while MODIS maximum values are almost equal for spring (MAM) and summer (JJA), being 0.168 and 0.167 , respectively. In terms of temporal variation, the least confidence in using HAC is during months with heavy aerosol conditions, such as March to May for the NH (due to desert dust) and from September to November for the SH (due to biomass burning).

Comparing the spectral dependence of HAC AOD to that of MODIS and AERONET it was found that there are sites where HAC might overestimate fine-mode aerosols, hence exhibiting a stronger spectral dependence at ultraviolet wavelengths $(300-440 \mathrm{~nm})$. On the other hand, there is higher confidence in using the HAC spectral distribution at visible and infrared wavelengths. The new HAC climatology provides aerosol vertical profiles for the entire globe that are needed by radiative transfer and climate models, especially in that they are given separately for fine and coarse aerosols. The highest lifting of aerosols occurs in latitudes between the tropics and $30-40^{\circ} \mathrm{N}$, especially in the zone $20-30^{\circ} \mathrm{N}$, reaching altitudes of $5-6 \mathrm{~km}$. HAC also exhibits some aerosol over the Arctic, which is being transported from mid-latitudes. According to HAC, there are much less stratospheric aerosols over the corresponding southern polar latitudes, though in the Southern Hemisphere aerosols are found above $10 \mathrm{~km}$ in the Southern Ocean $\left(50-70^{\circ} \mathrm{S}\right)$, associated with coarse aerosols. The difference between the profiles of fine and coarse aerosols does not seem significant for either of the hemispheres, but in general fine aerosols are lifted higher up into the atmosphere than coarse aerosols in the Northern Hemisphere, while the opposite is true for the Southern Hemisphere. Globally, $50 \%$ of the total AOD is found up to the height of $1.50 \mathrm{~km}$, and $85 \%$ of the total AOD is found from the surface up to $3.22 \mathrm{~km}$ above mean sea level. The corresponding fractions for the $\mathrm{NH}$ are $1.42 \mathrm{~km}$ and $2.96 \mathrm{~km}$, whereas for the $\mathrm{SH}$ are 1.70 and $3.52 \mathrm{~km}$.

The HAC vertical distribution has been tested against version 3 data from CALIOP from the period July 2006January 2011. In the Mediterranean basin, HAC was found to have an almost perfect agreement for most of the tropospheric column, thereby providing high confidence for the use of the HAC vertical distribution. Looking at selected sites, representative of biomass burning smoke, desert dust and sea salt spray, it was found that in most cases HAC assumes less aerosol in the lower layers (GSFC, January and July up to $2 \mathrm{~km}$; Alta Floresta, from 2.2 to $5 \mathrm{~km}$; Tahiti, January and July; Dalanzadgad, January; Jabiru, January and July), The misplacement is usually smaller at the lower altitudes but increases as the altitude increases, with a peak usually at $4-5 \mathrm{~km}$. One likely reason is that the fraction of fine mode aerosols is overestimated in HAC and those aerosols are lifted more easily.

Despite the differences with ground-based and satellite observations, the HAC data for aerosol optical depth (AOD) can be used with confidence in aerosol studies, offering advantages such as high spectral resolution and global coverage, availability of vertically distributed AOD data as well as information on fine and coarse AOD. The implementation of the HAC aerosol data, including single scattering albedo and asymmetry parameter, in a spectral radiation transfer model is the scope of ongoing work aiming at the quantification of anthropogenic/natural aerosol radiative forcings.

\section{Supplementary material related to this article is available online at: http://www.atmos-chem-phys.net/13/ 8381/2013/acp-13-8381-2013-supplement.pdf.}

Acknowledgements. This research has been co-financed by the European Union (European Social Fund - ESF) and Greek national funds through the operational programme "Education and Lifelong Learning" of the National Strategic Reference Framework (NSRF) - Research Funding Program: THALES. Investing in knowledge society through the European Social Fund. The AeroCom (http://nansen.ipsl.jussieu.fr/AeroCom) global modelling effort was essential to this study, as the (16) model median provides the starting point for the new aerosol climatology (HAC). Thus the work of all global modelling groups 
that contributed to AeroCom is particularly acknowledged. All AeroCom-based HAC data used here are freely available on the ftp site (ftp://ftp-projects.zmaw.de/AeroCom/Climatology/feb_2010). The authors thank NASA-US for making available the Collection 005 Level-3 MODIS data. We thank the principal investigators and their staff for establishing and maintaining the 5 AErosol RObotic NETwork (AERONET) sites used in this investigation. We also thank the CALIPSO Science Team for their efforts in making data products publicly available. CALIOP data were obtained from the NASA Langley Research Center Atmospheric Science Data Center.

Edited by: X. Querol

\section{References}

Abel, S. J., Highwood, E. J., Haywood, J. M., and Stringer, M. A.: The direct radiative effect of biomass burning aerosols over southern Africa, Atmos. Chem. Phys., 5, 1999-2018, doi:10.5194/acp-5-1999-2005, 2005.

Chatterjee, A., Michalak, A. M., Kahn, R. A., Paradise, S. R., Braverman, A. J., and Miller, C. E.: A geostatistical data fusion technique for merging remote sensing and ground-based observations of aerosol optical thickness, J. Geophys. Res., 115, D20207, doi:10.1029/2009JD013765, 2010.

Chin, M., Ginoux, P., Kine, S., Torres, O., Holben, B. N., Duncan, B. N., Martin, R. V., Logan, J. A., Higurashi, A., and Nakajima, T.: Tropospheric aerosol optical thickness from the GOCART model and comparisons with satellite and Sun photometer measurements, J. Atmos. Sci., 59, 461-483, 2002.

Chu, D. A., Kaufman, Y. J., Ichoku, C., Remer, L. A., Tanre, D., and Holben, B. N.: Validation of MODIS aerosol optical depth retrieval over land, Geophys. Res. Lett., 29, 8007, doi:10.1029/2001GL013205, 2002.

Chung, C.E., Ramanathan, V., Carmichael, G., Kulkarni, S., Tang, Y., Adhikary, B., Leung, L.R., and Qian, Y.: Anthropogenic aerosol radiative forcing in Asia derived from regional models with atmospheric and aerosol data assimilation, Atmos. Chem. Phys., 10, 6007-6024, doi:10.5194/acp-10-6007-2010, 2010.

De Graaf, M., Stammes, P., and Aben, E. A. A.: Analysis of reflectance spectra of UV-absorbing aerosol scenes measured by SCIAMACHY, J. Geophys. Res., 112, D02206, doi:10.1029/2006JD007249, 2007.

Diner, D. J., Beckert, J. C., Reilly, T. H., Bruegge, C. J., Conel, J. E., Kahn, R. A., Martonchik, R. A., Ackerman, T. P., Davies, R., Gerstl, S., Gordon, H. R., Muller, J.-P., Myneni, R., Sellers, P., Pinty, B., and Verstraete, M.: Multi-angle Imaging Spectro Radiometer (MISR) instrument description and experiment overview, IEEE T. Geosci. Remote, 36, 1072-1087, 1998.

Dubovik, O., Sinyuk, A., Lapyonok, T., Holben, B. N., Mishchenko, M., Yang, P., Eck, T. F., Volten, H., Munoz, O., Veihelmann, B., van der Zande, W. J., Leon, J-F, Sorokin, M. and Slutsker, I.: Application of spheroid models to account for aerosol particle nonsphericity in remote sensing of desert dust. J. Geophys. Res., 111, D11208, doi:10.1029/2005JD006619, 2006.

Eck, T. F., Holben, B., N., Dubovik, O., Smirnov, A., Goloub, P., Chen, H. B., Chatenet, B., Gomes, L., Zhang, X.-Y., Tsay, S.C., Ji, Q., Giles, D., and Slutsker, I.: Columnar aerosol optical properties at AERONET sites in central eastern Asia and aerosol transport to the tropical mid-Pacific, J. Geophys. Res., 110, D06202, doi:10.1029/2004JD005274, 2005.

Fearnside, P. M.: Global warming and tropical land-use change: Greenhouse gas emissions from biomass burning, decomposition and soils in forest conversion, shifting cultivation and secondary vegetation, Clim. Change, 46, 115-158, 2000.

Ferrare, R. A., Turner, D. D., Clayton, M., Guibert, S., Schulz, M., and Chin, M.: The vertical distribution of aerosols over the atmospheric radiation measurement Southern Great Plains Site, Measured versus Modelled. Fifteenth ARM Science Team Meeting Proceedings, Daytona Beach, Florida, March 14-18, 2005.

Grey, W. M. F., North, P. R. J., Los, S. O., and Mitchell, R. M.: Aerosol Optical Depth and Land Surface Reflectance From MultiAngle AATSR Measurements: Global Validation and Intersensor Comparisons, IEEE Trans. Geosci. Remote Sens., 44, 2184 2197, 2006.

Hatzianastassiou, N., Katsoulis, B., and Vardavas, I.: Global distribution of aerosol direct radiative forcing in the ultraviolet and visible arising under clear skies, Tellus B, 56, 51-71, 2004a.

Hatzianastassiou, N., Katsoulis, B., and Vardavas, I.: Global distribution of aerosol direct radiative forcing in the ultraviolet and visible arising under clear skies, Tellus, 56, 51-71, 2004b.

Herman, J. R., Barthia, P. K. Torres, O. Hsu, C. Seftor C., and Celarier, E.: Global distribution of UV-absorbing aerosols from Nimbus 7/TOMS data, J. Geophys. Res., 102, 16911-16922, doi:10.1029/96JD03680, 1997.

Holben, B. N., Setzer, A., Eck, T. F., Pereira, A., and Slutsker, I.: Effect of dry-season biomass burning on Amazon basin aerosol concentrations and optical properties, 1992-1994, J. Geophys. Res., 101, 19465-19481, doi:10.1029/96JD01114, 1996.

Holben, B. N., Tanre, D., Smirnov, A., Eck, T. F., Slutsker, I., Abuhassan, N., Newcomb, W. W., Schafer, J. S., Chatenet, B., Lanevu, F., Kaufman, Y. J., Vande Castle, J., Setzer, A., Markham, B., Clark, D., Frouin, R., Halthore, R., Karneli, A., O’Neill, N. T., Pietras, C., Pinker, R. T., Voss, K., Zibordi, G.: An emerging ground-based aerosol climatology: Aerosol Optical Depth from AERONET, J. Geophys. Res., 106, 12067-12097, doi:10.1029/2001JD900014, 2001.

Hyer, E. J., Reid, J. S., and Zhang, J.: An over-land aerosol optical depth data set for data assimilation by filtering, correction, and aggregation of MODIS Collection 5 optical depth retrievals, Atmos. Meas. Tech., 4, 379-408, doi:10.5194/amt-4-379-2011, 2011.

Ichoku, C., Chu, D. A., Mattoo, S., Kaufman, Y. J., Remer, L. A., Tanré, D., Slutsker, I., and Holben, B. N.: A spatio-temporal approach for global validation and analysis of MODIS aerosol products, Geophys. Res. Lett., 29, 8006, doi:10.1029/2001GL013206, 2002.

Intergovernmental Panel on Climate Change (IPCC): Summary for Policymakers. in: Climate Change 2007: The Physical Science Basis, Contribution of Working Group I to the Fourth Assessment Report of the Intergovernmental Panel on Climate Change, edited by: Solomon, S., Qin, D., Manning, M., Chen, Z., Marquis, M., Averyt, K. B., Tignor, M., and Miller, H. L., Cambridge University Press, Cambridge, United Kingdom and New York, NY, USA, 1-8, 2007.

Johnson, B. T., Shine, K. P., and Forster, P. M.: The semi-direct aerosol effect: Impact of absorbing aerosols on marine stratocumulus, Q. J. R. Meteorol. Soc., 130, 1407-1422, 2004. 
Johnson, B. T., Osborne, S. R., Haywood, J. M., and Harrison, M. A. J.: Aircraft measurements of biomass burning aerosol over West Africa during DABEX, J. Geophys. Res., 113, D00C06, doi:10.1029/2007JD009451, 2008.

Johnson, M. S., Meskhidze, N., Kiliyanpilakkil, V. P., and Gassó, S.: Understanding the transport of Patagonian dust and its influence on marine biological activity in the South Atlantic Ocean, Atmos. Chem. Phys., 11, 2487-2502, doi:10.5194/acp-11-24872011, 2011.

Kaskaoutis, D. G., Nastos, P. T., Kosmopoulos, P. G., and Kambezidis, H. D.: Characterising the long-range transport mechanisms of different aerosol types over Athens, Greece during 2000-2005, Int. J. Climatol., 32, 1249-1270, doi10.1002/joc.2357, 2011.

Kaufman, Y. J., Tanré, D., Gordon, H. R., Nakajima, T., Lenoble, J., Frouin, R., Grassl, H., Herman, B. M., King, M. D., and Teillet, P. M.: Passive remote sensing of tropospheric aerosol and atmospheric correction for the aerosol effect, J. Geophys. Res., 102, 16815-16830, 1997.

Kim, D. H., Sohn, B. J., Nakajima, T., Takamura, T., Takemura, T., Choi, B. C., and Yoon, S. C.: Aerosol optical properties over East Asia determined from ground-based sky radiation measurements, J. Geophys. Res., 109, D02209, doi:10.1029/2003JD003387, 2004.

King, M. D., Kaufmann, Y. J., Tanré, D., and Nakajima, T.: Remote sensing of tropospheric aerosols from space: Past, present and future. Bull. Am. Meteorol. Soc., 80, 2229-2259, 1999.

Kinne, S.: Climatologies of cloud related aerosols, Part 1: Particle number and size, in: Clouds in the perturbed climate system, edited by: Heintzenberg, J. and Charlson, R., ISBN: 978-0-26201287-4, Mass, MIT Press, Cambridge, 37-57, 2008.

Kinne, S., Schulz, M., Textor, C., Guibert, S., Balkanski, Y., Bauer, S. E., Berntsen, T., Berglen, T. F., Boucher, O., Chin, M., Collins, W., Dentener, F., Diehl, T., Easter, R., Feichter, J., Fillmore, D., Ghan, S., Ginoux, P., Gong, S., Grini, A., Hendricks, J., Herzog, M., Horowitz, L., Isaksen, I., Iversen, T., Kirkevåg, A., Kloster, S., Koch, D., Kristjansson, J. E., Krol, M., Lauer, A., Lamarque, J. F., Lesins, G., Liu, X., Lohmann, U., Montanaro, V., Myhre, G., Penner, J., Pitari, G., Reddy, S., Seland, O., Stier, P., Takemura, T., and Tie, X.: An Aerocom initial assessment - optical properties in aerosol component modules of global models, Atmos. Chem. Phys., 6, 1815-1834, doi:10.5194/acp-6-1815-2006, 2006.

Kinne, S., O’ Donnel, D., Stier, P., Kloster, S., Zhang, K., Schmidt, H., Rast, S., Giorgetta, M., Eck, T., and Stevens, B.: A new global aerosol climatology for climate studies, Atmos. Chem. Phys., in preparation, 2012.

Kondo, Y., Matsui, H., Moteki, N., Sahu, L., Takegawa, N.,, Kajino, M., Zhao, Y., Cubison, M. J., Jimenez, J. L., Vay, S., Diskin, G. S., Anderson, B., Wisthaler, A., Mikoviny, T., Fuelberg, H. E., Blake, D. R., Huey, G., Weinheimer, A. J., Knapp, D. J., and Brune, W. H.: Emissions of black carbon, organic, and inorganic aerosols from biomass burning in North America and Asia in 2008, J. Geophys. Res., 116, D08204, doi:10.1029/2010JD015152, 2011.

Lau, K. M., Kim, M. K., and Kim, K. M.: Asian summer monsoon anomalies induced by aerosol direct forcing: the role of the Tibetan Plateau, Clim. Dyn., 26, 855-864, doi:10.1007/s00382006-0114-z, 2006.
Lelieveld, J., Berresheim, H., Borrmann, S., Crutzen, P. J., Dentener, F. J., Fischer, H., Feichter, J., Flatau, P. J., Heland, J., Holzinger, R., Korrmann, R., Lawrence, M. G., Levin, Z., Markowicz, K. M., Mihalopoulos, N., Minikin, A., Ramanathan, V., de Reus, M., Roelofs, G. J., Scheeren, H. A., Sciare, J., Schlager, H., Schultz, M., Steil, B., Stephanou, E. G., Stier, P., Traub, M., Warneke, C., Williams, J., and Ziereis, H.: Global Air Pollution Crossroads over the Mediterranean, Science, 298, 794799, 2002.

Levy, R. C., Remer, L. A., Tanreì, D., Kaufman, Y. J., Ichoku, C., Holben, B. N., Livingston, J. M., Russell, P. B., and Maring, H.: Evaluation of the Moderate-Resolution Imaging Spectroradiometer (MODIS) retrievals of dust aerosol over the ocean during PRIDE, J. Geophys. Res., 108, 8594, doi:10.1029/2002JD002460, 2003.

Levy, R. C., Remer, L. A., Martins, J. V., Kaufman, Y. J., PlanaFattori, A., Redemann, J., and Wenny, B.: Evaluation of the MODIS aerosol retrievals over ocean and land during CLAMS, J. Atmos. Sci., 62, 974-992, 2005.

Levy, R. C., Remer, L. A., and Dubovik, O.: Global aerosol optical properties and application 15 to Moderate Resolution Imaging Spectroradiometer aerosol retrieval over land, J. Geophys. Res., 112, D13210, doi:10.1029/2006JD007815, 2007a.

Levy, R. C., Remer, L. A., Mattoo, S., Vermote, E. F., and Kaufman, Y. J.: Second-generation operational algorithm: Retrieval of aerosol properties over land from inversion of moderate resolution imaging spectroradiometer spectral reflectance, J. Geophys. Res., 112, D13211, 20 doi:10.1029/2006JD007811, 2007b.

Levy, R. C., Remer, L. A., Kleidman, R. G., Mattoo, S., Ichoku, C., Kahn, R., and Eck, T. F.: Global evaluation of the Collection 5 MODIS dark-target aerosol products over land, Atmos. Chem. Phys., 10, 10399-10420, doi:10.5194/acp-10-10399-2010, 2010.

Liousse, C., Penner, J. E., Chuang, C., Walton, J. J., Eddleman, H., and Cachier, H.: A global three-dimensional model study of carbonaceous aerosols, J. Geophys. Res., 101, 19,411-19,432, doi:10.1029/95JD03426, 1996.

Liu, D., Wang, Z., Liu, Z., Winker, D., and Trepte, C.: A height resolved global view of dust aerosols from the first year CALIPSO lidar measurements, J. Geophys. Res., 113, D16214, doi:10.1029/2007JD009776, 2008.

Matsui, H., Kondo, Y., Moteki, N., Takegawa, N., Sahu, L. K., Zhao, Y., Fuelberg, H. E., Sessions, W. R., Diskin, G., Blake, D. R., Wisthaler, A., and Koike, M.: Seasonal variation of the transport of black carbon aerosol from the Asian continent to the Arctic during the ARCTAS aircraft campaign, J. Geophys. Res., 116, D05202, doi:10.1029/2010JD015067, 2011.

Mlawer, E. J., Taubman, S. J., Brown, P. D., Iacono, M. J., and Clough, S. A.: Radiative transfer for inhomogeneous atmospheres: RRTM, a validated correlated-k model for the longwave. J. Geophys. Res., 102, doi:10.1029/97JD00237, 1997.

Mona, L., Pappalardo, G., Amodeo, A., D’Amico, G., Madonna, F., Boselli, A., Giunta, A., Russo, F., and Cuomo, V.: One year of CNR-IMAA multi-wavelength Raman lidar measurements in coincidence with CALIPSO overpasses: Level 1 products comparison, Atmos. Chem. Phys., 9, 7213-7228, doi:10.5194/acp-97213-2009, 2009.

Papadimas, C. D., Hatzianastassiou, N., Mihalopoulos, N., Kanakidou, M., Katsoulis, B. D., and Vardavas, I.: Assessment of the MODIS Collections C005 and C004 aerosol optical depth prod- 
ucts over the Mediterranean basin, Atmos. Chem. Phys., 9, 29872999, 2009,

http://www.atmos-chem-phys.net/9/2987/2009/.

Pappalardo, G., Wandinger, U., Mona, L., Hiebsch, A., Mattis, I., Amodeo, A., Ansmann, A., Seifert, P., Holger, L., Apituley, A., Arboledas, L. A., Balis, D., Chaikovsky, A., D’Amico, G., De Tomasi, F., Freudenthaler, V., Giannakaki, E., Giunta, A., Grigorov, I., Iarlori, M., Madonna, F., Mamouri, R. E., Nasti, L., Papayannis, A., Pietruczuk, A., Pujadas, M., Rizi, V., Rocadenbosch, F., Russo, F., Schnell, F., Spinelli, N., Wang, X., and Wiegner, M. : EARLINET correlative measurements for CALIPSO: First intercomparison results, J. Geophys. Res., 115, D00H19, doi:10.1029/2009JD012147, 2010.

Pappas, V., Ryder, C. L., Highwood, E. J., and Stuart, Y.: Comparison of Fennec airborne in situ-dust measurements with CALIOP spaceborne lidar retrievals of extinction, submitted, 2013.

Penner, J. E., Quaas, J., Storelvmo, T., Takemura, T., Boucher, O., Guo, H., Kirkevåg, A., Kristjánsson, J. E., and Seland, Ø.: Model intercomparison of indirect aerosol effects, Atmos. Chem. Phys., 6, 3391-3405, doi:10.5194/acp-6-3391-2006, 2006.

Powell, K. A., Hostetler, C. A., Liu, Z. Y., Vaughan, M. A., Kuehn, R. E., Hunt, W. H., Lee, K. P., Trepte, C. R., Rogers, R. R., Young, S. A., and Winker, D. M.: CALIPSO Lidar Calibration Algorithms, Part I: Night-time 532-nm Parallel Channel and 532nm Perpendicular Channel, J. Atmos. Ocean. Tech., 26, 20152033, 2009.

Qin, Y. and Mitchell, R. M.: Characterisation of episodic aerosol types over the Australian continent, Atmos. Chem. Phys., 9, 1943-1956, doi:10.5194/acp-9-1943-2009, 2009.

Ramanathan, V., Crutzen, P. J., Kiehl, J. T., and Rosenfeld, D.: Aerosols, climate, and the hydrological cycle, Science, 294, 2119-2124, 2001.

Remer, L. A., Tanré, D., Kaufman, Y. J., Ichoku, C., Mattoo, S., Levy, R., Chu, D. A., Holben, B., Dubovik, O., Smirnov, A., Martins, J. V., Li, R.-R., and Ahman, Z.: Validation of MODIS aerosol retrieval over ocean, Geophys. Res. Lett., 29, 8008, doi:10.1029/2001GL013204, 2002.

Remer, L. A., Kaufman, Y. J., Tanre, D., Mattoo, S., Chu, D. A., Martins, J. V., Li, R. R., Ichoku, C., Levy, R. C., Kleidman, R. G., Eck, T. F., Vermote, E., and Holben, B. N.: The MODIS aerosol algorithm, products, and validation, J. Atmos. Sci., 62, 947-973, 2005.

Remer, L. A., Kleidman, R. G., Levy, R. C., Tanré, D., Mattoo, S., Vanderlei Martins, J., Ichoku, Ch., Koren, I., Yu, H., and Holben, B. N: An emerging aerosol climatology from the MODIS satellite sensors, J. Geophys. Res., 113, D14S07, doi:10.1029/2007JD009661, 2008.

Roberts, G., Wooster, M. J., and Lagoudakis, E.: Annual and diurnal african biomass burning temporal dynamics, Biogeosciences, 6 , 849-866, doi:10.5194/bg-6-849-2009, 2009.

Rogers, R. R., Hostetler, C. A., Hair, J. W., Ferrare, R. A., Liu, Z., Obland, M. D., Harper, D. B., Cook, A. L., Powell, K. A., Vaughan, M. A., and Winker, D. M.: Assessment of the CALIPSO Lidar $532 \mathrm{~nm}$ attenuated backscatter calibration using the NASA LaRC airborne High Spectral Resolution Lidar, Atmos. Chem. Phys., 11, 1295-1311, doi:10.5194/acp-11-12952011, 2011.

Sayer, A. M., Thomas, G. E., and Grainger, R. G.: A sea surface reflectance model for (A)ATSR, and application to aerosol re- trievals, Atmos. Meas. Tech., 3, 813-838, doi:10.5194/amt-3813-2010, 2010.

Shaw, G. E.: Antarctic aerosols: A review, Rev. Geophys., 26, 89112, 1988.

Smirnov, A., Holben, B. N., Slutsker, I., Giles, D. M., McCLain, C. R., Eck, T. F., Sakerin, S. M., Macke, A., Croot, P., Zibordi, G., Quinn, P. K., Sciare, J., Kinne, S., Harvey, M., Smyth, T. J., Piketh, S., Zielinski, T., Proshuninsky, A., Goes, J. I., Nelson, N. B., Larouche, P., Radionov, V. F., Goloub, P., Moorthy, K. K., Matarresse, R., Robertson, E. J., and Jourdin, F.: Maritime Aerosol Network as a component of Aerosol Robotic Network, J. Geophys. Res., 112, D06204, doi:10.1029/2008JD011257, 2009.

Stier, P., Seinfeld, J. H., Kinne, S., and Boucher, O.: Aerosol absorption and radiative forcing, Atmos. Chem. Phys., 7, 5237-5261, doi:10.5194/acp-7-5237-2007, 2007.

Su, W., N. G. Loeb, K.-M. Xu, G. L. Schuster, and Z. A. Eitzen: An estimate of aerosol indirect effect from satellite measurements with concurrent meteorological analysis, J. Geophys. Res., 115, D18219, doi:10.1029/2010JD013948, 2010.

Swap, R. J., Garstang, M., Macko, S. A., Tyson, P. D., Maenhaut, W., Artaxo, P., Kallberg, P., and Talbot, R.: The long-range transport of southern African aerosol to the tropical South Atlantic, J. Geophys. Res., 101, 23777-23791, doi:10.1029/95JD01049, 1996.

Takemura, T., Nakajima, H. T., Dubovik, O., Holben, B. N., and Kinne, S.: Single-scattering albedo and radiative forcing of various aerosol species with a global three-dimensional model, J. Climate, 15, 333-352, 2002.

Textor, C., Schulz, M., Guibert, S., Kinne, S., Balkanski, Y., Bauer, S., Berntsen, T., Berglen, T., Boucher, O., Chin, M., Dentener, F., Diehl, T., Easter, R., Feichter, H., Fillmore, D., Ghan, S., Ginoux, P., Gong, S., Grini, A., Hendricks, J., Horowitz, L., Huang, P., Isaksen, I., Iversen, I., Kloster, S., Koch, D., Kirkevåg, A., Kristjansson, J. E., Krol, M., Lauer, A., Lamarque, J. F., Liu, X., Montanaro, V., Myhre, G., Penner, J., Pitari, G., Reddy, S., Seland, $\emptyset$., Stier, P., Takemura, T., and Tie, X.: Analysis and quantification of the diversities of aerosol life cycles within AeroCom, Atmos. Chem. Phys., 6, 1777-1813, doi:10.5194/acp-6-1777-2006, 2006.

Treffeisen, R. E., Thomason, L. W., Ström, J., Herber, A. B., Burton, S. P., and Yamanouchi, T.: Stratospheric Aerosol and Gas Experiment (SAGE) II and III aerosol extinction measurements in the Arctic middle and upper troposphere, J. Geophys. Res., 111, D17203, doi:10.1029/2005JD006271, 2006.

Vardavas, I. M and Taylor, F. W.: Radiation and Climate. Atmospheric energy budget from satellite remote sensing, International Series of Monographs on Pysics 138, Oxford University Press, Oxford, 2011.

Vuolo, M. R., Chepfer, H., Menut, L., and Cesana, G.: Comparison of mineral dust layers vertical structures modeled with CHIMERE-DUST and observed with the CALIOP lidar, J. Geophys. Res.-Atmospheres, 114, D09214, doi:10.1029/2008JD011219, 2009.

Winker, D. M., Hunt, W. H., and McGill, M. J.: Initial performance assessment of CALIOP, Geophys. Res. Lett., 34, L19803, doi:10.1029/2007GL030135, 2007.

Yu, H., Kaufman, Y. J., Chin, M., Feingold, G., Remer, L. A., Anderson, T. L., Balkanski, Y., Bellouin, N., Boucher, O., Christopher, S., DeCola, P., Kahn, R., Koch, D., Loeb, N., Reddy, 
M. S., Schulz, M., Takemura, T., and Zhou, M.: A review of measurement-based assessments of the aerosol direct radiative effect and forcing, Atmos. Chem. Phys., 6, 613-666, doi:10.5194/acp-6-613-2006, 2006.

Yu, H., Chin M., Winker, D. M., Omar, A. H., Liu, Z., Kittaka, C., and Diehl, T.: Global view of aerosol vertical distributions from CALIPSO lidar measurements and GOCART simulations: Regional and seasonal variations, J. Geophys. Res., 115, D00H30, doi:10.1029/2009JD013364, 2010.
Zhang, J. and Reid, J. S.: A decadal regional and global trend analysis of the aerosol optical depth using a data-assimilation grade over-water MODIS and Level 2 MISR aerosol products, Atmos. Chem. Phys., 10, 10949-10963, doi:10.5194/acp-1010949-2010, 2010.

Zhao, T. X. P., Dubovik O., Smirnov A., Holben B. N., Sapper J., Pietras C., Voss K. J., and Frouin R.: Regional evaluation of an advanced very high resolution radiometer (AVHRR) two-channel aerosol retrieval algorithm. J. Geophys. Res., 109, D02204, doi:10.1029/2003JD003817, 2004. 